\title{
Long-term variability of aerosol optical thickness in Eastern Europe over 2001-2014 according to the measurements at the Moscow MSU MO AERONET site with additional cloud and $\mathrm{NO}_{2}$ correction
}

\author{
N. Y. Chubarova, A. A. Poliukhov, and I. D. Gorlova \\ Moscow State University, Faculty of Geography, 119991, Moscow, Russia \\ Correspondence to: N. Y. Chubarova (chubarova@geogr.msu.ru) \\ Received: 18 June 2015 - Published in Atmos. Meas. Tech. Discuss.: 29 July 2015 \\ Revised: 28 December 2015 - Accepted: 14 January 2016 - Published: 3 February 2016
}

\begin{abstract}
The atmospheric aerosol properties were obtained within the framework of the AERONET program at the Moscow State University Meteorological Observatory (Moscow MSU MO) over the 2001-2014 period. The quality data control has revealed the necessity of additional cloud screening and $\mathrm{NO}_{2}$ correction. The application of additional cloud screening according to hourly visual cloud observations provides a decrease in monthly average aerosol optical thickness (AOT) at $500 \mathrm{~nm}$ of up to 0.03 compared with the standard data set. We also show that the additional $\mathrm{NO}_{2}$ correction of the AERONET version 2 data is needed in large megalopolis, like Moscow, with 12 million residents and $\mathrm{NO}_{x}$ emission rates of about $100 \mathrm{kt} \mathrm{yr}^{-1}$. According to the developed method, we estimated monthly mean $\mathrm{NO}_{2}$ content, which provides an additional decrease of 0.01 for AOT at $340 \mathrm{~nm}$, and of about 0.015 - for AOT at 380 and $440 \mathrm{~nm}$. The ratios of $\mathrm{NO}_{2}$ optical thickness to AOT at 380 and $440 \mathrm{~nm}$ are about $5-6 \%$ in summer and reach $15-20 \%$ in winter when both factors have similar effects on UV irradiance. Seasonal cycle of AOT at $500 \mathrm{~nm}$ is characterized by a noticeable summer and spring maxima, and a minimum in winter conditions, changing from 0.08 in December and January up to 0.3 in August. The application of the additional cloud screening removes a local AOT maximum in February. Statistically significant negative trends in annual AOT for UV and mid-visible spectral range have been obtained both for average and $50 \%$ quantile values. The pronounced negative changes were observed in most months with the rate of about $-1-5 \% \mathrm{yr}^{-1}$ and could be attributed to the negative trends in emissions $(E)$ of different aerosol precursors of about $135 \mathrm{Gg} \mathrm{yr}^{-2}$ in $E_{\mathrm{SO}_{x}}, 54 \mathrm{Gg} \mathrm{yr}^{-2}$ in $E_{\mathrm{NMVOC}}$, and slight negative changes in $\mathrm{NO}_{x}$ over the European part of
\end{abstract}

Russia. No significant influence of natural factors on temporal AOT variations has been revealed.

\section{Introduction}

Atmospheric aerosols are among the most important factors influencing net radiation at the top and at the bottom of the atmosphere and, therefore, affecting the whole climate system (IPCC, 2013). However, still there is not enough information about their optical properties over different geographical regions. The knowledge of long-term variations of aerosol optical thickness can significantly affect the assessment of climate change, and at the same time can be an indicator of changes in emissions of aerosol precursors (Tegen et al., 1997).

It is possible to retrieve different aerosol properties from observations by satellite instruments, i.e., Advanced Very High Resolution Radiometer (AVHRR), Moderate Resolution Imaging Spectroradiometer (MODIS), Advanced Along-Track Scanning Radiometer (AATSR), medium-spectral resolution, imaging spectrometer MERIS, Polarization and Directionality of the Earth's Reflectances (POLDER), Ozone Monitoring Instrument (OMI), Cloud-Aerosol Lidar and Infrared Pathfinder Satellite Observations (CALIPSO), Sea-Viewing Wide Field-of-View Sensor (SeaWiFs), Multi-angle Imaging Spectroradiometer (MISR), etc. (IPCC, 2013). However, still the ground-based measurements are the most accurate and serve as a reference for comparisons. Ground-based aerosol networks such as Global Atmosphere Watch Precision Filter Radiometers (GAW-PFR), AErosol RObotic 
NETwork (AERONET), observation network SKYNET, Siberian system for aerosol research (SibRad), provide high quality aerosol measurements (http://www.wmo.int/pages/ prog/arep/gaw/aerosol.html). Aerosol Robotic Network (AERONET) (http://aeronet.gsfc.nasa.gov/) has been in operation since the middle of the 1990s (Holben et al., 1998) with currently more than 400 sites continuously working all over the world. AERONET is equipped with CIMEL sun/sky photometers, which provide accurate measurements of direct solar irradiance and multi-angle sky radiance from UV to near-infrared spectral region for evaluating aerosol optical thickness and many other inversion products including size distribution, effective radii, aerosol phase function, and different optical and radiative aerosol properties - refractive index, single scattering albedo, asymmetry factor, etc. (Dubovik and King, 2000).

In order to eliminate the cases, which are degraded by cloud-contamination, a special cloud-screening procedure has been used in the AERONET algorithm (Smirnov et al., 2000). In addition, in the second version of the AERONET data set (Holben et al., 2006) a correction for the effect of several optically effective trace gases $\left(\mathrm{NO}_{2}, \mathrm{O}_{3}, \mathrm{CO}_{2}, \mathrm{H}_{2} \mathrm{O}\right.$, $\mathrm{CH}_{4}$ ) has been applied to the measurements in different channels.

The continuous aerosol measurements at the Moscow State University Meteorological Observatory (Moscow MSU $\mathrm{MO}$ ) within the AERONET program have been in operation since August 2001. These records provide a reliable data set for studying long-term variability of aerosol properties in Eastern Europe, where the aerosol network coverage is sparse. In addition, the auxiliary hourly cloud visual observations and measurements of different trace gases at the MSU MO over the whole period of observations provide the data for testing the existing AERONET algorithms and for improving the quality of the aerosol data set. This is important since one can see still the effects of residual thin, homogeneous, upper-layer cloud contamination in aerosol retrievals even in the final AERONET data set (O'Neill et al., 2003; Uliumdjieva et al., 2005; Chew et al., 2011; Huang et al., 2012). One of the tasks of this paper is to demonstrate the effects of the additional cloud-screening procedure and $\mathrm{NO}_{2}$ correction on evaluation of aerosol climatology in Moscow. Using the revised aerosol data set, we studied the seasonal features and long-term aerosol optical thickness (AOT) variability over the 2001-2014 period. We also tried to find explanation of the obtained AOT trend in Moscow and to analyze the influence of possible natural and human induced factors on its character.

\section{Data description}

The procedure of aerosol measurements by CIMEL AERONET sun/sky photometer and the inversion algorithms were described in numerous publications (http://aeronet.gsfc. nasa.gov/new_web/publications.html). MSU MO site uti- lizes the $1.2^{\circ}$ full field of view CIMEL CE318 sun and sky photometer. The direct solar radiation measurements in the $340,380,440,500,675,870$, and $1020 \mathrm{~nm}$ channels are used for aerosol optical thickness retrievals; the measurements in the $940 \mathrm{~nm}$ channel are used for the evaluation of water vapor content. In addition, direct spectral irradiance measurements are applied for the retrievals of fine and coarse aerosol modes according to the spectral deconvolution algorithm (O'Neill et al., 2001, 2003). Both sun and sky radiances in the channels $440,675,870$ and $1020 \mathrm{~nm}$ are utilized in the inversion algorithm developed by Dubovik and King (2000), which provides several important aerosol products (volume size distribution, refractive index, single scattering albedo, phase function, etc.). The uncertainty of aerosol optical thickness measurements does not exceed 0.01 in visible range and $0.02-$ in the UV spectral range (Eck et al., 1999; Holben et al., 2001). However, there are some important but still not fully resolved problems, which include testing and further improvement of cloud-screening algorithm and the additional correction on $\mathrm{NO}_{2}$ in large megalopolis like Moscow. For the improvement of these procedures, we used visual cloud observations with $1 \mathrm{~h}$ resolution. The uncertainty of visual cloud amount measurements is about 1 or 2 cloud fraction (in tenth) according to Mazin and Hrgian (1989); however, the conditions with overcast or zero cloudiness are observed accurately by any observer. In addition, the data set of hourly solar disk condition observations, which are performed simultaneously with cloud observations, was used in the analysis. This is a standard type of observation at the actinometrical stations in Russia. Using this characteristic we can discern the conditions, when solar disk (SD) is free from clouds, or when SD is obscured by thin clouds but shadows at ground can be observed, or when SD can be seen but there are no shadows at ground, or when SD can not be seen due to relatively high cloud optical thickness. These SD conditions are noted with "2", "1", " 0 " and " $P$ " marks, respectively.

For quantifying the $\mathrm{NO}_{2}$ content, we used long-term $1 \mathrm{~min}$ resolution in situ measurements of $\mathrm{NO}_{2}$ concentrations by APNA-360, Horiba Inc. (Elansky et al., 2007) at the Moscow MSU MO at the altitude of about $3.5 \mathrm{~m}$ from ground since 2002. The $\mathrm{NO}_{2}$ data were used as the input parameters in the developed algorithm described in Chubarova et al., 2009 for the independent evaluation of $\mathrm{NO}_{2}$ content in the low troposphere over urban Moscow area. The details of the methods and the results are discussed below in the next section. In addition, we used some standard meteorological and radiative measurements at the Meteorological Observatory of Moscow State University which are described directly in the text. 


\section{Results}

\subsection{The effects of the additional cloud screening and $\mathrm{NO}_{2}$ correction on aerosol climatology}

\subsubsection{Additional cloud-screening procedure and its effect on aerosol climatology}

Since the aerosol measurements are carried out in automatic regime, a special cloud-screening procedure has been developed for an automatic removal of cloud contaminating aerosol measurements (Smirnov et al., 2000). In the standard AERONET algorithm, the data, which successfully pass the cloud-screening procedure, are assigned to the level 1.5. After the second calibration and some additional visual checks the data are assigned to the final level 2.0. However, sometimes even the final data set could be affected by the effects of contamination by thin, homogeneous cloudiness (O'Neill et al., 2003). As stated in the aforementioned paper, "the strategy of the AERONET cloud screening was liberal; to interfere as little as possible with coarse mode events such as dust incursions and thus to accept the inevitability of some thin, homogeneous cloud data, being admitted into the database." Hence, the following questions remain. How important is this effect? Will it significantly affect the aerosol climatology?

For evaluating the cloud contamination by thin, homogeneous cloudiness in the AERONET data set, different approaches are used. In recent studies the ground-based Micro-Pulse Lidar Network (MPLNET), as well as satellite CALIPSO and MODIS data sets were applied for assessing the cirrus AOT contamination (Chew et al., 2011; Huang et al., 2012). According to MPLNET data, the AOT bias due to unscreened cirrus cloud presence is about $0.03-0.06$, with the occurrence of 23-34\% depending on the method of the estimation over the tropical region in Singapore (Chew et al., 2011). Huang et al. (2012) evaluated the susceptibility percentage of AERONET level 2.0 AOT retrievals to cirrus contamination using different types of measurements. According to MPLNET cirrus flags, this value varied from zero to $\sim 4 \%$, according to the collocated Calipso cirrus flags - from $1 \%$ to $33 \%$, and according to the MODIS cirrus flags - from 0.4 to $18 \%$ changing significantly over the globe due to the different occurrence of cirrus clouds. However, satellites have relatively low overpass frequency over AERONET sites - onetwo times a day - for MODIS, and a 16-day repeating cycle - for CALIPSO (Huang et al., 2012). The MPLNET application for cirrus flags has a problem with viewing geometry difference between the sunphotometer and the MPL. In addition, the MPL signals are extremely weak at the altitudes $H>10 \mathrm{~km}$, where cirrus clouds may be observed. It was also mentioned in Huang et al., 2012 that the MPL noise level dramatically increases during daytime especially at noon, when favorable conditions for AERONET-MPLNET matchup occur from the point of view of the closeness of viewing geometries.
The influence of cloud contamination on aerosol properties was also discussed in Uliumdzhieva et al., 2005 for Moscow conditions. In this paper, the application of the standard cloud visual observations as an additional cloudscreening filter was proposed. We used $1 \mathrm{~h}$ resolution cloud observations for additional filtering of quasi-simultaneous Cimel observations at the same site. The application of cloud filter means the elimination of all AOT measurements for the entire hour interval. We showed there that the existing standard cloud-screening algorithm works perfectly, when aerosol measurements are contaminated by optically thin low layer cloudiness, which is characterized by large triplet variations. These variations are used as a parameter in the standard cloud-screening algorithm developed by Smirnov et al. (2000). However, if the cloud blocking the Sun is thin and uniform, the triplet variation can be small and the contaminated AOT measurements pass through the filter. Mainly the cirrus clouds are characterized by these properties. However, in general, according to the International Cloud Atlas (1987) other types of clouds may be also characterized by these properties as well. They include different forms of cirrostratus, and even altostratus translucidus clouds, which relate to the middle cloud level. In this publication all types of the cloudiness, which can induce the potential contamination of AOT will be combined under the term "optically thin, homogeneous cloudiness". However, in majority of cases they refer to the upper level cloudiness.

Since low cloudiness is effectively filtered out by the standard cloud-screening algorithm, we proposed to apply simple total cloud amount (NA) filter, which is sensitive to the existence of optically thin, homogeneous cloudiness. In this context, NA value (together with the application of standard cloud-screening procedure) provides the information about the potential existence of high and middle layer cloudiness, since the standard AERONET cloud-screening algorithm successfully removes the cases contaminated by low level clouds, since optically thin low layer clouds are almost always characterized by strong signal variations. However, the application of different NA thresholds may provide different samples and, as a result, different statistics. As an example, in Fig. 1 we demonstrate the effects of utilizing the different additional NA filters for AOT at $500 \mathrm{~nm}$ (AOT500) and Angstrom exponent $(\alpha)$ data sets for the central months of the seasons. At the confidence level of $P=80 \%$ several of these dependencies are statistically significant (see the error bars in Fig. 1). One can see a similar tendency of the AOT decrease in all seasons in the NA $<9$ sample after removing the cases in almost overcast conditions with total cloud amount of NA $=9-10$. Additional testing on solar disk conditions has revealed that all eliminated cases in this sample belong to situations, when solar disk was covered by clouds $(\mathrm{SD}=1$ or $\mathrm{SD}=0$ ). In April after eliminating the almost overcast cloud conditions in the NA $<9$ sample there is no further changes in AOT500 with more strict NA cloud thresholds. At the same time, the sample is dramatically reduced to less than half 

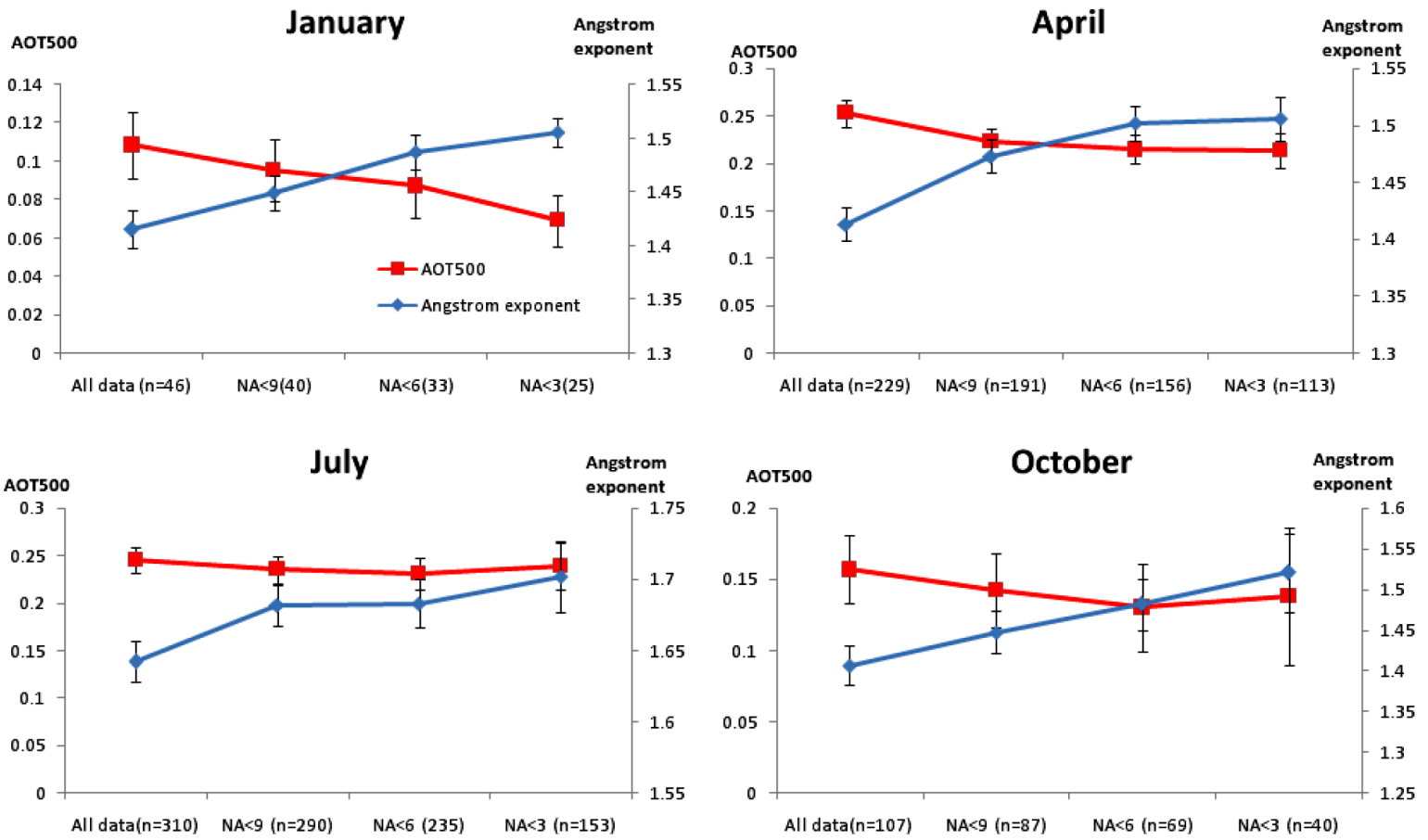

Figure 1. Mean aerosol optical thickness at $500 \mathrm{~nm}$ (AOT500) and Angstrom exponent within 440-870 nm spectral range in different samples with various total cloud amount (NA) thresholds for the central months of the seasons. Number of days with measurements for each sample is given in brackets. Error bars are shown at the confidence level $P=80 \%$. The data were taken from the standard version 2 AERONET data set (Moscow, 2001-2014).

from 229 to 113 in the NA < 3 sample. In July we also see a slight decrease in AOT500 in the NA $<9$ sample and, in addition, a significant growth of Angstrom exponent. Note that in July and October we see even a slight increase in AOT500 for quasi-clear sky conditions (the NA $<3$ sample). In January there is a pronounced reduction in AOT500 when cloud amount decreases. The lowest AOT500 values and largest Angstrom exponent are observed in the NA $<3$ sample. The application of the $24 \mathrm{~h}$ Hybrid Single-Particle Lagrangian Integrated Trajectory (HYSPLIT) NOAA model backward trajectory analysis (Draxler and Hess, 1998) for all the cases in January has revealed for the NA $<3$ sample the prevalence of the northern (north-west, north, north-east) advection ( $80 \%$ of cases) characterized by low AOT (Chubarova, 2009), compared with $40 \%$ of cases for partially cloudy conditions $(3<\mathrm{NA}<9)$. Hence, we should emphasize that quasiclear sky conditions NA $<3$ data set may not reflect the typical aerosol features due to large-scale meteorological effects and possible changes in aerosol properties in the vicinity of clouds (Eck et al., 2014).

Balancing between the substantial decrease in case number and the accuracy of the retrievals of aerosol properties we showed that during March-October period robust results were obtained with NA $=9$ threshold when only the observations in almost overcast cloudiness and $100 \%$ cloudcontaminated solar disk conditions were removed from the data set. For November-February conditions the filter threshold is more strict $(\mathrm{NA}<6)$ since solar elevation in Moscow is low $\left(h_{\text {noon }}<25^{\circ}\right)$ at this time and a well-known effect of significant visual cloud amount increase towards the horizon plays a vital role. More strict cloud threshold during winter time may induce filtering out the "good" AOT cases at open Sun disk conditions. According to the probability laws, the percent of conditions when Sun is un-obscured by clouds should be $20 \%$ if the equal probability is observed for cloud amount from NA $=6$ to $\mathrm{NA}=10$. However, in Moscow this probability is different. During winter according to cloud statistics obtained for conditions with sun photometer measurements, the overcast cloud cover is prevailing (NA $=10$ with $P=54 \%$ ). In these conditions the Sun is totally obscured by optically thin clouds. Visual increase of cloud amount towards the horizon in situation with low solar elevation during November-February mentioned above also decreases the probability of un-obscured Sun at smaller NA. The additional analysis of solar disk conditions has revealed only 12 cases (about $0.5 \%$ ) from the total $\mathrm{N}=2521$, which were not contaminated by clouds $(\mathrm{SD}=2)$ and were incorrectly removed from the sample. All of them were observed in February (18 February $2011-4$ cases at NA = 8; 3 February $2003-5$ cases at NA $=6 ; 11$ February $2007-3$ cases at NA $=6$ ). Even the data from these 3 days are presented in 
(a)

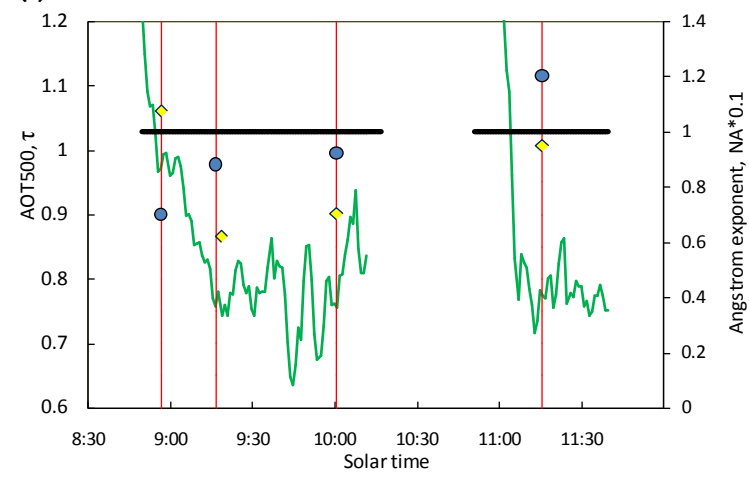

(b)

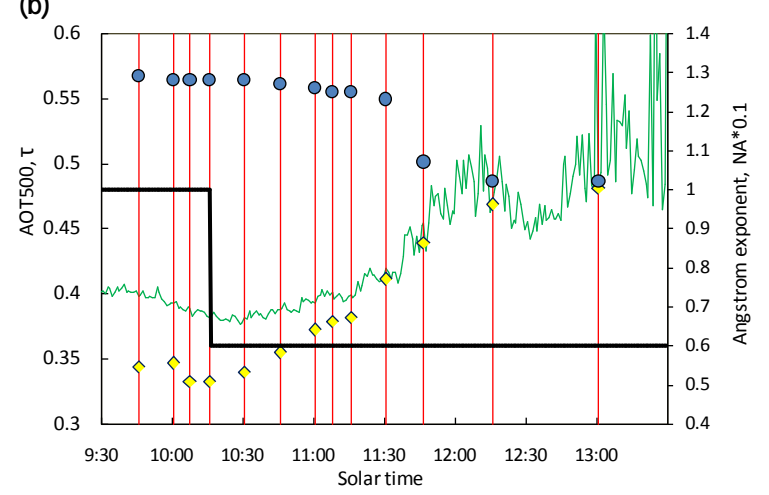

Figure 2. The time series in AOT500 (diamonds), integral optical thickness $\tau$ (green line), Angstrom exponent (circles), and total cloud amount NA*0.1 (black lines) during 27 February 2005 (a) and 1 February 2006 (b) in the contaminated cloud conditions. AOT500 and the Angstrom exponent were taken from the standard version 2 AERONET data set. Note that $\tau$ is given only as an indicator of aerosol/cloud stability conditions during the AERONET measurements. See further details in the text.

the final sample since other sun photometer measurements at smaller NA were available during these days.

In addition, we analyzed the $1 \mathrm{~min}$ resolution direct solar measurements with the standard Russian actinometer (WMO, 1986) for studying the possibility of AERONET direct solar irradiance observations in cloud gaps. These data were used for estimating the standard transparency coefficient at air mass $m=2$ according to (Evnevich and Savikovsky, 1989):

$$
p_{2}=\left(\frac{S_{h}}{1.367}\right)^{\frac{\sinh +0.205}{1.41}} \text {, }
$$

where $S_{h}$ - is the measured value of direct shortwave irradiance, $h$ - solar elevation.

The $p_{2}$ coefficient is widely used for assessing the variation of the transparency of the atmosphere (Ohvril et al., 2009). Using this characteristic, we estimated the integral optical thickness as $\tau=-\ln \left(p_{2}\right)$.

The 1 min resolution time series of integral optical thickness $\tau$ were used as the indicator of the cloud gap existence during the CIMEL sun photometer measurement since the duration of the measurement triplet taken with the CIMEL is also about $1 \mathrm{~min}$. We assume that if Sun is un-obscured by clouds in the moment of the CIMEL AOT measurement, the lowest $\tau$ value for this moment compared with the adjacent $\tau$ observations should be obtained. Note that we used the $\tau$ data series only as an indicator of high frequency solar irradiance signal variations and we do not consider their absolute values.

For illustrating this phenomenon, Fig. 2 presents the diurnal variations of $1 \mathrm{~min}$ resolution $\tau$, as well as AERONET level 2.0 AOT500 and Angstrom exponent data series in cloud contamination conditions, which finally were removed from the revised data set, during the 2 days -27 February 2005 and 1 February 2006. Weather conditions on 27 February 2005 were characterized by the presence of cirrus, cir- rocumulus and altocumulus clouds. Solar disk was covered by thin clouds $(\mathrm{SD}=1)$, the NA cloud amount was equal to 10. We can see that on 27 February 2005 AOT500 observations do not correspond to the smallest $\tau$ values around AERONET record, and, hence, there were no cloud gaps conditions during AOT500 measurements (Fig. 2a). Similar results were obtained on 1 February 2006, when during the entire day cirrus clouds with $\mathrm{NA}=10$ and NA $=6$ were observed (Fig. 2b). The morning conditions were characterized by thin overcast cloudiness with $\mathrm{NA}=10, \mathrm{SD}=1$ and low AOT500. The Angstrom exponent in the morning was relatively high, that means that cirrus clouds were very thin. During the day the cloud amount decreased from NA $=10$ to $\mathrm{NA}=6$. Despite the decrease in cloud amount, we can see the gradual increase in AOT500 and $\tau$ data as well as reducing in Angstrom exponent values. This means that the cloud distribution was not uniform on the celestial hemisphere and clouds were located in the Sun disk zone that was also confirmed by $\mathrm{SD}=1$. The gradual increase in AOT and the decrease in $\alpha$ values indicate that the clouds were getting more optically dense. Note that even $\mathrm{SD}=0$ conditions were observed after noon time. The $\tau$ time series with $1 \mathrm{~min}$ resolution around AERONET AOT500 measurements do not demonstrate any local decrease, but rather more uniform distribution which enable the AERONET data to pass through the standard cloud-screening procedure. Of course, there can be cloud gap conditions during AERONET AOT measurements; however, on average, leaving the cloud-contaminated cases in aerosol climatology may induce much larger bias than removal of few "good" cases. By this example we also illustrate the necessity of the additional more strict cloud screening in winter with the threshold equal to $\mathrm{NA}=6$.

Using this approach we obtained a revised data set with additional visual cloud screening over the whole 2001-2014 period of observations in Moscow. Figure 3a, b shows the absolute and relative differences between the standard monthly 

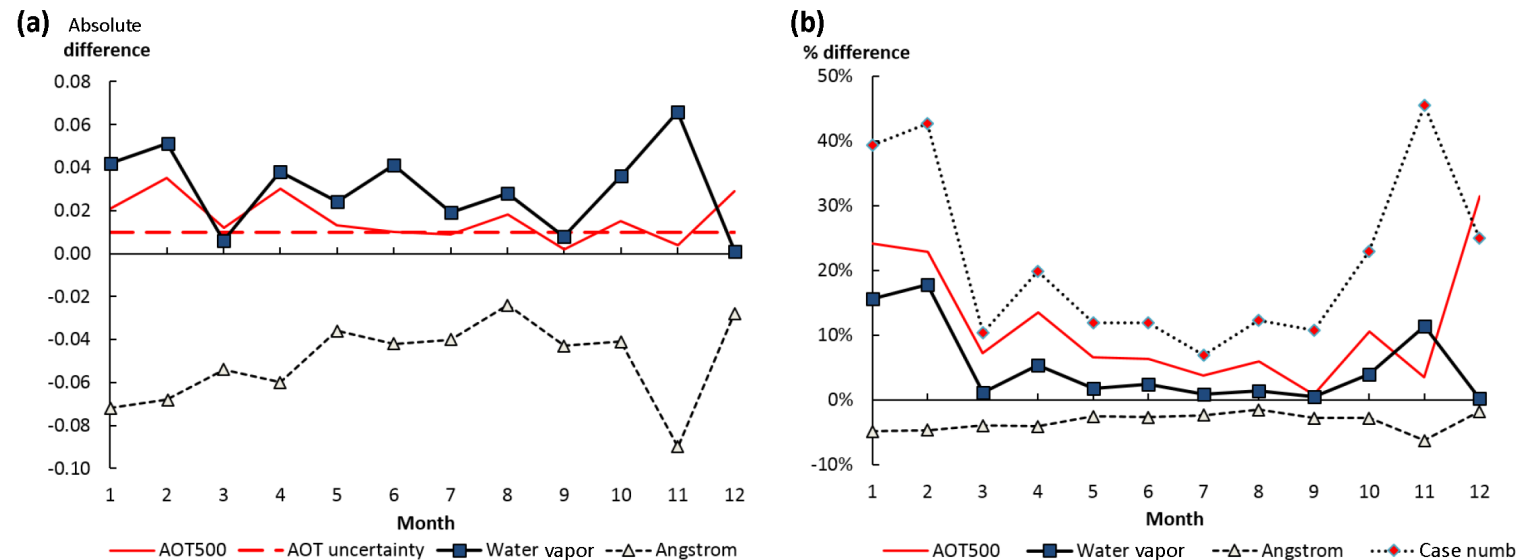

Figure 3. The absolute (a) and relative (b) difference of monthly mean standard level 2.0 data on aerosol optical thickness at $500 \mathrm{~nm}$ (AOT500), Angstrom exponent and water vapor content with the data set after the additional cloud screening. The standard uncertainty of AOT measurements is shown in Fig. 2a. Relative changes in day number removed after the additional cloud screening is shown in Fig. $2 b$. Note that in Fig. 2a the difference in water vapor content is given in $\mathrm{cm}$ and other characteristics are dimensionless (Moscow, 2001-2014).

mean aerosol optical thickness at $500 \mathrm{~nm}$ (AOT500) and additionally cloud-screened AOT500 values, as well as the differences in water vapor content, Angstrom exponent, and variation in day number over the whole period of measurements. One can see systematically higher values of monthly mean aerosol optical thickness at $500 \mathrm{~nm}$ in the standard AERONET data set up to 0.03 for several months. For all months (except September and November) the difference is higher than 0.01 , which corresponds to the uncertainty of AOT measurements ( $\varepsilon=0.01$, depicted by the line in Fig. 3 ). In some years the monthly mean difference can even exceed 0.1 (for example, in February 2005 and October 2012). A detailed analysis was made to understand the reasons of these large discrepancies with the standard AERONET AOT data set. Figure 4 shows the comparison between the standard daily mean AOT500 and Angstrom exponent data and their values after additional cloud filtering. In February 2005 an additional cloud filtering provided the full elimination of measurements during 3 and 27 February 2005, which were characterized by smaller Angstrom exponent and extremely high AOT on 27 February 2005. According to the additional checks we found that all these cases were observed in solar disk conditions with $\mathrm{SD}=1$ or $\mathrm{SD}=0$. The additional cloud filtering also provides a slight increase in Angstrom exponent during the other days in February 2005, that might also indirectly confirm the elimination of cloud-contaminated cases. In October 2012 the application of the additional cloud filter provided the removal of high AOT500 values on 4 October 2012 due to the existence of overcast cloud conditions with $\mathrm{SD}=1$. However, a relatively high Angstrom exponent ( $\alpha=1.28$ according to the standard AERONET data set) indicated that cloudiness was optically thin and finemode aerosol dominated during this day. During the other days in October the difference in both aerosol characteristics obtained before and after the additional cloud screening was negligible.

Due to existing AOT seasonal change the relative difference in AOT500 has a noticeable minimum in summer (5\%) and the increase up to $20-30 \%$ during winter months when the occurrence of optically thin, homogeneous cloudiness is high and AOT is low. There is also discernible underestimation of Angstrom exponent in the standard AERONET data set due to the influence of close to neutral scattering on large cloud droplet, which contaminate AOT values applied in the Angstrom exponent evaluation. The relative bias in Angstrom exponent has also some tendency towards higher underestimation (from -1 to $-6 \%$ ) in the standard product during the cold period. Both positive AOT difference and negative Angstrom exponent difference may indicate the reliable elimination of cloud-contaminated cases after the application of additional cloud filter. It is interesting that water vapor content is also overestimated in cloud-contaminated conditions up to $0.05-0.07 \mathrm{~cm}$ (or 15-20\%) during winter months possibly due to the additional absorption by ice and water particles. However, there could be another reason for this phenomenon: the air convergence may create favorable conditions with higher relative humidity for both larger water vapor content and cloud generation (Jeong and Li, 2010). These processes should be studied further in the future.

After the application of an additional cloud filter the day number significantly decreases (see Fig. 3b): up to 7-20\% during the warm period, and $25-45 \%$ in the cold period due to higher occurrence of overcast optically thin, homogeneous cloudiness and the application of more strict filter NA $<6$. Note that a small number of days with aerosol observations in winter due to cloudy conditions results in large relative changes of the removed day number even when only 1-2 days are eliminated from the initial statistics. These val- 

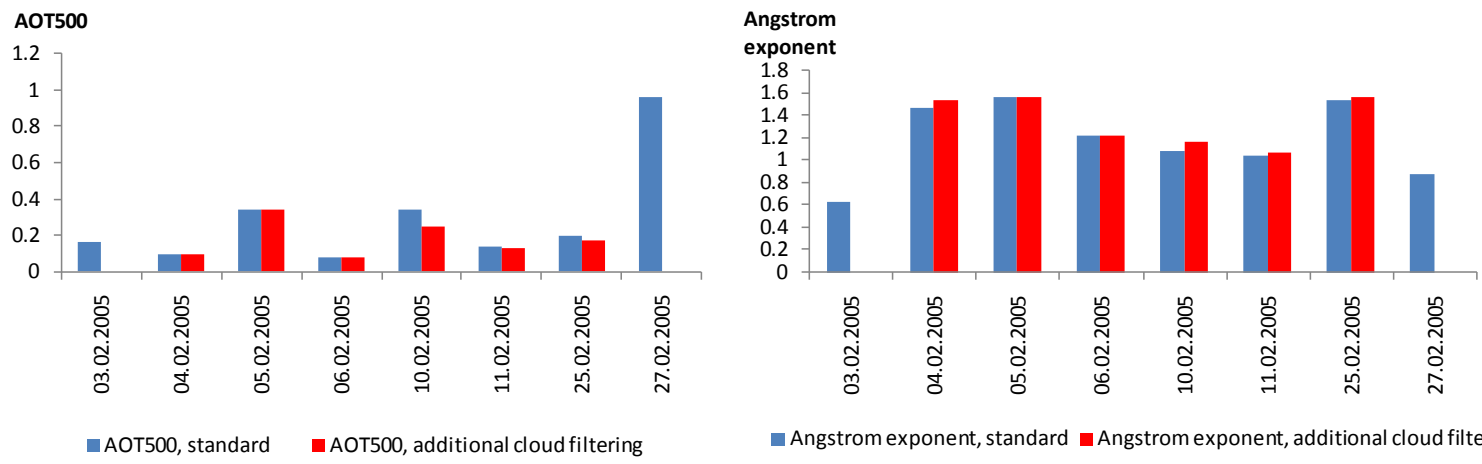

Angstrom exponent, standard $\square$ Angstrom exponent, additional cloud filtering
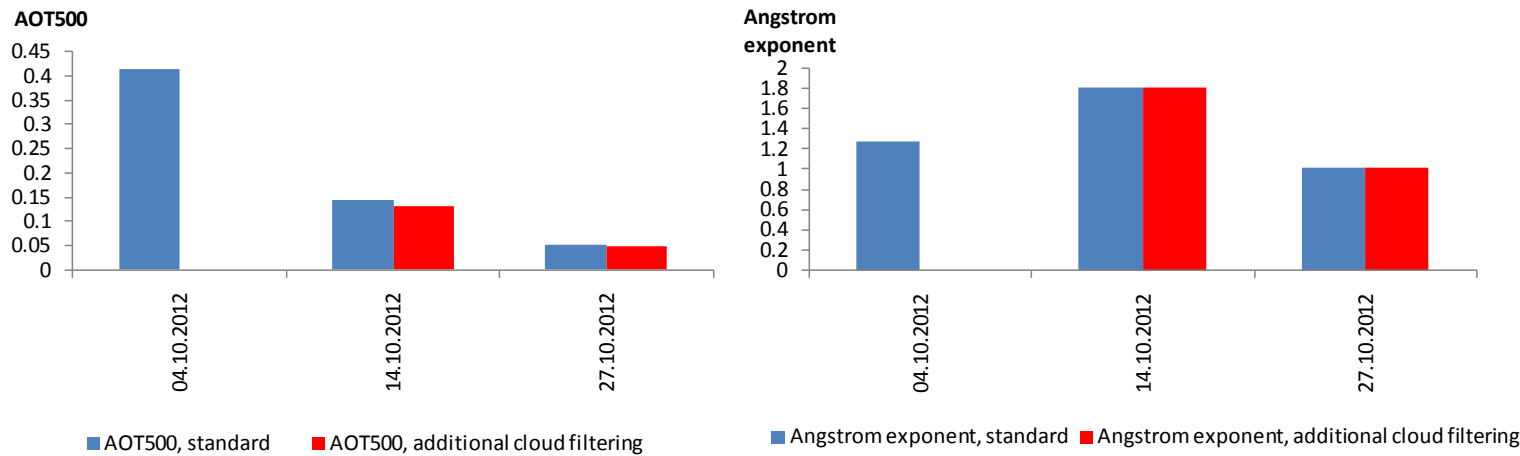

Figure 4. Standard AERONET AOT500 and Angstrom exponent daily means and their values after the application of the additional cloud screening for the months with large monthly mean AOT bias from the standard AERONET data set (February 2005, upper panels; October 2012, lower panels). Note that the absence of the red columns (revised data set) for several days means full elimination of the aerosol measurements after additional cloud checking. The solar disk was obscured by cirrus, cirrocumulus, and cirrostratus clouds during both days with $\mathrm{SD}=1$, and $\mathrm{SD}=0$. The halo was detected. See further description in the text.

ues are in a qualitative agreement with the cirrus susceptibility percentage of the AERONET level 2.0 AOT data according to the CALIPSO vertical feature masks (Huang et al., 2012), but they differ from the assessments obtained using the Micro-Pulse Lidar data shown in the same paper. However, the application of the Micro-Pulse Lidar data for evaluating the cirrus cloud contamination over tropical areas (Chew et al., 2011) has revealed much higher susceptibility percentage (about 23-34\%) of the AOT sample, which is in qualitative accordance with our data for winter months.

However, several recent studies indicated that clouds can have a real impact on AOT. These mechanisms of aerosolcloud interaction include aerosol hygroscopic growth, increasing aerosol concentration due to air convergence, and new particles formation in the presence of clouds (Su et al., 2008; Jeong and Li, 2010; Eck et al., 2012, 2014). In addition to the well-known process of hygroscopic particle growth, there is a mechanism of the gas-to-particle conversion that occurs more intensively in the aqueous phase in cloud droplets due to the oxidation of gases $\left(\mathrm{SO}_{2}, \mathrm{NO}_{x}\right.$, SOA) (Eck et al., 2014). Due to this mechanism in the presence of convective cloudiness the formation of new aerosol particles may observe providing higher aerosol loading dur- ing the periods with higher cloud amount in the vicinity of clouds (Eck et al., 2014).

Another mechanism of simultaneous variations in both aerosol and cloud amount is the changes in meteorology conditions, when, depending on advection and circulation features one can obtain synchronous changes in AOT and cloud amount, which do not interact with each other. A good example of this effect is the noticeable dependence of AOT and Angstrom exponent on various cloud filters for January. As discussed above, according to the results of $24 \mathrm{~h}$ HYSPLIT backward trajectory analysis the collocated changes in AOT and cloud amount (value of cloud filter, see Fig. 1) are likely observed due to the changes in advection. However, during the warm period according to our long-term data set we did not obtain the AOT-cloud amount dependence, except $100 \%$ contaminated cases when the NA $<9$ threshold filter has been applied. We should also mention that after applying this filter, which removes the data when solar disk was blocked by optically thin, homogeneous clouds, we do not remove any other cases with different cloud types, except those, which have been removed by the standard AERONET cloud-screening algorithm. However, it will be interesting to compare the results with the soon-to-be-released AERONET version 3 data set, where a modification of standard cloud-screening algo- 
rithm will be applied to the data according to the method mentioned in Eck et al., 2014.

\subsection{2 $\mathrm{NO}_{2}$ correction algorithm and the effects of the revised $\mathrm{NO}_{2}$ climatology on AOT estimations}

The version 2 AERONET algorithm includes the correction on different trace gases content (http://aeronet.gsfc.nasa.gov/ new_web/Documents/spectral_corrections_v2.pdf). Among them, nitrogen dioxide $\left(\mathrm{NO}_{2}\right)$ has a significant absorption in the UV range and in several visible channels, especially over the urban/industrial areas.

We should emphasize that Moscow is a large megalopolis with significant level of $\mathrm{NO}_{x}$ emission of about $100 \mathrm{kt} \mathrm{yr}^{-1}$ (Ivanov et al., 2012). According to the data of Mosecomonitoring agency the actual $\mathrm{NO}_{2}$ surface concentrations in clean background conditions near Moscow are about $70 \%$ lower than those observed in Moscow (Kulbachevski, 2014). The spectral correction of aerosol optical thickness on $\mathrm{NO}_{2}$ in the AERONET algorithm is made according to the SCIAMACHY climatology data over the 2003-2005 period (http: //www.temis.nl/airpollution/no2.html) (Eskes et al., 2003). However, other studies have revealed much higher $\mathrm{NO}_{2}$ content over Moscow (Ivanov et al., 2012). According to the satellite data, the $\mathrm{NO}_{2}$ tropospheric content over megacities reaches high levels (Hiboll et al., 2013). Our aerosol comparisons in urban and background conditions (Chubarova et al., 2011) also demonstrated the existence of the residual $\mathrm{NO}_{2}$ contamination over Moscow, which can be seen in a specific character of AOT spectral difference between the parallel measurements in Moscow and in Zvenigorod background conditions at the distance of $55 \mathrm{~km}$ (see Fig. 3 and the discussion in Chubarova et al., 2011). This residual $\mathrm{NO}_{2}$ contamination is caused by much higher $\mathrm{NO}_{2}$ content in Moscow than that accounted for in the AERONET algorithm.

In order to analyze the effects of $\mathrm{NO}_{2}$ underestimation in AOT retrievals over urban Moscow area, we applied the algorithm for evaluating the $\mathrm{NO}_{2}$ content, which has been developed recently (Chubarova et al., 2009, 2010). To account for the $\mathrm{NO}_{2}$ amount up to the height of $350 \mathrm{~m}$ we utilized the developed parameterizations of its content within $350 \mathrm{~m}$ according to in situ long-term $\mathrm{NO}_{2}$ measurements in the boundary layer from ground to $350 \mathrm{~m}$ at several points of Moscow (at the Ostankino tower and at the top of Moscow State University Building) during summer and winter conditions to account for possible differences in meteorological factors like boundary layer altitude, temperature and photochemistry effects. These data were combined with the results of a photochemical model, which had been adapted to the available experimental data on different chemical constituents and meteorological conditions in the boundary layer. Input model parameters include the spectral flux of solar radiation, absorption cross sections and quantum yields of photodissociation products, rate constants of chemical reactions, the altitude temperature profiles, turbulent diffusion coefficients, concentrations of some atmospheric components, and meteorological parameters that were measured during the experiments (Chubarova et al., 2010). The applied 1-D photochemical model calculated the vertical profiles with $50 \mathrm{~m}$ resolution up to $20 \mathrm{~km}$ and took into account for several hundreds of chemical reactions for 100 components. We also used the temperature profiles from Microwave Temperature Profiler MTP5 (Kadygrov et al., 2003) up to $600 \mathrm{~m}$ for the evaluation of the diffusion coefficients to account for the different boundary layer conditions. As a result, various weighting coefficients for summer and winter conditions were evaluated for different layers: 0-350, 350-1000, and $1000-2000 \mathrm{~m}$. According to these data, we obtained two regimes of $\mathrm{NO}_{2}$ vertical distribution typical for Moscow conditions within the low $2 \mathrm{~km}$ layer. Note that tropospheric and especially boundary layer $\mathrm{NO}_{2}$ content in urban areas has the most important contribution to the total $\mathrm{NO}_{2}$ content and is several times higher than that in background conditions (Richter et al., 2005; Hiboll et al., 2013). For the altitudes higher than $2 \mathrm{~km}$ we applied the climatological $\mathrm{NO}_{2}$ values according to numerous data of aircraft measurements (Bruns et al., 2006; Heland et al., 2002; Martin et al., 2006). They are about $0.1 \mathrm{ppb}$ for the altitudes of $2-5 \mathrm{~km}$, and are characterized by linear decrease to approximately $0.01 \mathrm{ppb}$ at $12 \mathrm{~km}$. In the stratosphere, the $\mathrm{NO}_{2}$ profile corresponds to the data published in Bruns, 2004 according to the direct measurements in Europe and North America. The total $\mathrm{NO}_{2}$ content at altitudes higher than $2 \mathrm{~km}$ is relatively small, comprising about 0.24 DU. $\left(0.6 \times 10^{16} \mathrm{~mol} \mathrm{~cm}^{-2}\right)$.

Figure 5a and Table 1 show the resulting monthly mean $\mathrm{NO}_{2}$ content obtained according to the proposed method. One can see that the maximum $\mathrm{NO}_{2}$ content is observed in February and elevated $\mathrm{NO}_{2}$ values are recorded in December-March period due to higher emissions from power stations during the heating season and larger $\mathrm{NO}_{2}$ lifetime in winter conditions due to the decreasing of the photodissociation rates at higher zenith angles (Brasseur and Solomon, 1986). Figure 5a also demonstrates seasonal variations of $\mathrm{NO}_{2}$ content, which are/ used in the standard AERONET algorithm. One can see that the new $\mathrm{NO}_{2}$ climatology is 2-3 times higher than the standard AERONET $\mathrm{NO}_{2}$ climatology, which is applied in the AERONET aerosol correction algorithm. Since these $\mathrm{NO}_{2}$ amounts were obtained for the 2003-2005 period, we also compared them with the $\mathrm{NO}_{2}$ retrievals over the same period according to the proposed method. As it is seen in Fig. 5a, not any statistically significant difference between the revised $\mathrm{NO}_{2}$ content climatology is detected between the 2002-2013 and 2003-2005 periods.

The values obtained from the new $\mathrm{NO}_{2}$ climatology are consistent with the results of accurate direct $\mathrm{NO}_{2}$ retrievals using the MAX-DOAS algorithm (Ivanov et al., 2012) over the same MSU MO site. We have good agreement with these MAX-DOAS $\mathrm{NO}_{2}$ estimates for 15 months of collocated observations. Mean difference between our $\mathrm{NO}_{2}$ retrievals and 

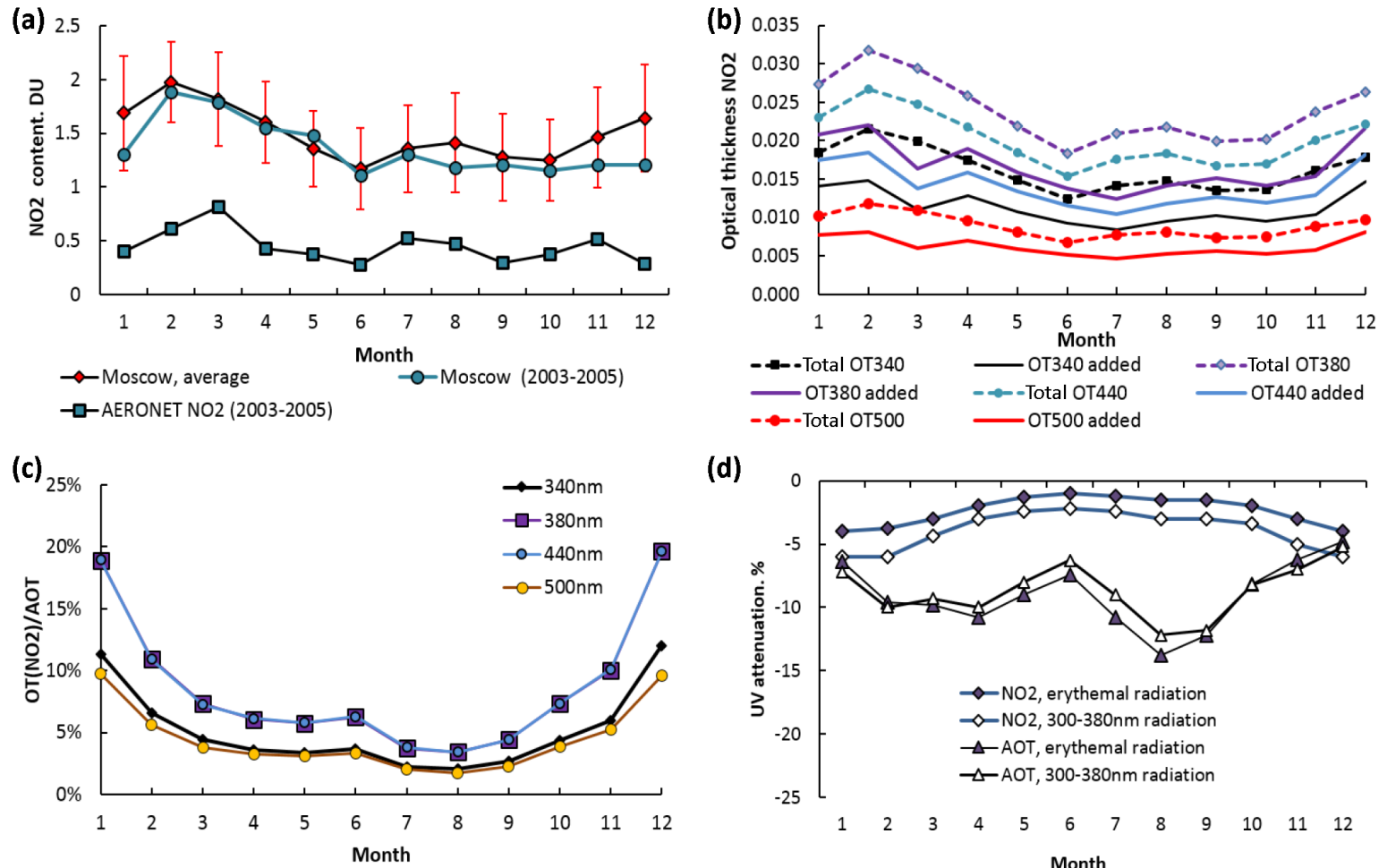

(d)

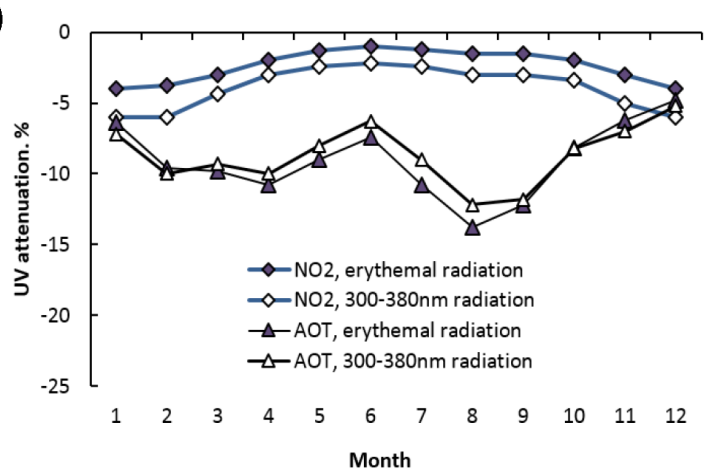

Figure 5. The seasonal distribution of mean $\mathrm{NO}_{2}$ content over the 2002-2013 and 2003-2005 periods obtained according to (Chubarova et al., 2010) and the $\mathrm{NO}_{2}$ retrievals applied in the standard AERONET algorithm (a); monthly mean total and additional optical thickness (OT) of $\mathrm{NO}_{2}$ at different wavelengths $(\mathbf{b})$; monthly mean ratio OT $\left(\mathrm{NO}_{2}\right)$ / AOT at different wavelengths (c); relative attenuation of erythemal radiation and UV radiation $300-380 \mathrm{~nm}$ due to $\mathrm{NO}_{2}$ and AOT at noon time conditions according to the results of 8-stream DISORT method (d) (Moscow).

Table 1. The monthly mean total $\mathrm{NO}_{2}$ content according to the new climatology and $\mathrm{NO}_{2}$ used in the standard AERONET algorithm; total $\mathrm{NO}_{2}$ optical thickness at different wavelengths, and the difference in Angstrom exponent obtained with and without additional $\mathrm{NO}_{2}$ correction of aerosol optical thickness at different wavelengths (Moscow, 2002-2013).

\begin{tabular}{|c|c|c|c|c|c|c|c|c|}
\hline \multirow[t]{2}{*}{ Months } & \multirow[t]{2}{*}{$\begin{array}{l}\text { Total }^{\mathrm{a}} \mathrm{NO}_{2} \\
\text { content, } \mathrm{DU}^{\mathrm{a}}\end{array}$} & \multirow[t]{2}{*}{$\begin{array}{l}\mathrm{NO}_{2} \text { content used in the } \\
\text { standard AERONET algorithm }\end{array}$} & \multicolumn{4}{|c|}{$\begin{array}{l}\text { Total }^{\mathrm{a}} \mathrm{NO}_{2} \text { optical thickness } \\
\text { at different wavelengths, } \mathrm{nm}\end{array}$} & \multicolumn{2}{|c|}{$\begin{array}{c}\text { Difference in } \\
\text { Angstrom exponent }\end{array}$} \\
\hline & & & 340 & 380 & 440 & 500 & $\begin{array}{l}440- \\
870 \mathrm{~nm}\end{array}$ & $\begin{array}{l}340- \\
380 \mathrm{~nm}\end{array}$ \\
\hline 1 & 1.69 & 0.401 & 0.018 & 0.027 & 0.023 & 0.010 & -0.22 & 0.55 \\
\hline 2 & 1.96 & 0.607 & 0.022 & 0.032 & 0.027 & 0.012 & -0.15 & 0.38 \\
\hline 3 & 1.82 & 0.809 & 0.020 & 0.029 & 0.025 & 0.011 & -0.10 & 0.24 \\
\hline 4 & 1.60 & 0.429 & 0.017 & 0.026 & 0.022 & 0.010 & -0.08 & 0.21 \\
\hline 5 & 1.35 & 0.373 & 0.015 & 0.022 & 0.018 & 0.008 & -0.08 & 0.21 \\
\hline 6 & 1.13 & 0.278 & 0.012 & 0.018 & 0.015 & 0.007 & -0.09 & 0.22 \\
\hline 7 & 1.29 & 0.526 & 0.014 & 0.021 & 0.018 & 0.008 & -0.05 & 0.13 \\
\hline 8 & 1.34 & 0.474 & 0.015 & 0.022 & 0.018 & 0.008 & -0.05 & 0.12 \\
\hline 9 & 1.23 & 0.297 & 0.013 & 0.020 & 0.017 & 0.007 & -0.07 & 0.16 \\
\hline 10 & 1.24 & 0.371 & 0.014 & 0.020 & 0.017 & 0.007 & -0.11 & 0.29 \\
\hline 11 & 1.47 & 0.518 & 0.016 & 0.024 & 0.020 & 0.009 & -0.18 & 0.44 \\
\hline 12 & 1.62 & 0.285 & 0.018 & 0.026 & 0.022 & 0.010 & -0.33 & 0.78 \\
\hline year & 1.48 & 0.45 & 0.02 & 0.02 & 0.02 & 0.01 & -0.13 & 0.31 \\
\hline
\end{tabular}

a - total $\mathrm{NO}_{2}$ content partly includes the $\mathrm{NO}_{2}$ content which is applied in the standard AERONET correction algorithm. 
the MAX-DOAS data set is about $-2 \pm 12 \%$ (at $P=95 \%$ ) for monthly mean $\mathrm{NO}_{2}$ estimates, which were used for the $\mathrm{NO}_{2}$ aerosol correction.

The estimated $\mathrm{NO}_{2}$ optical thickness $\left(\mathrm{OT}_{\mathrm{NO}_{2}}\right)$ in different CIMEL spectral channels is shown in Fig. 5b. The most pronounced effects of $\mathrm{OT}_{\mathrm{NO}_{2}}=0.02-0.03 \pm 0.003$ are observed for 380 and $440 \mathrm{~nm}$ channels due to the strongest $\mathrm{NO}_{2}$ absorption there. At the same time, $\mathrm{NO}_{2}$ optical thickness obtained from the standard AERONET algorithm is much smaller and does not exceed $\mathrm{OT}_{\mathrm{NO}_{2}}=0.013$ at $380 \mathrm{~nm}$ in March. New $\mathrm{NO}_{2}$ climatology provides $\mathrm{NO}_{2}$ optical thickness, which is 2-4 times higher than the values in the standard AERONET data set for Moscow urban conditions. It should be emphasized that the added $\mathrm{OT}_{\mathrm{NO}_{2}}$ values are close to the uncertainty threshold of the aerosol optical thickness evaluation of $\sim 0.02$ at $340 \mathrm{~nm}$ and are usually higher or comparable with the uncertainty threshold for AOT at other wavelengths, especially in winter and spring conditions; this is necessary to take into account. The obtained monthly mean $\mathrm{NO}_{2}$ content can be considered to be a typical level for large megalopolis with 12 million residents and the NOx emission rates of about $100 \mathrm{kt} \mathrm{yr}^{-1}$.

The effect of $\mathrm{NO}_{2}$ content on the AOT retrievals is not very large and since there is no statistically significant trend in $\mathrm{NO}_{2}$ content over Moscow according to our data as well as according to satellite retrievals (Hiboll et al., 2013; Schneider et al., 2015), we suggest to account only for monthly mean $\mathrm{NO}_{2}$ values.

Since the uncertainty in AOT according to the additional correction on the revised $\mathrm{NO}_{2}$ optical thickness has a spectral character, the effect is also expressed in the retrievals of the Angstrom exponent $(\alpha)$. One can see in Table 1 a decrease (in absolute values) in the $\alpha_{440-870}$ retrievals of about $0.06-$ 0.3 for different months mainly due to the reduction of AOT at $440 \mathrm{~nm}$ after applying the higher values of $\mathrm{OT}_{\mathrm{NO}_{2}}$ from the new $\mathrm{NO}_{2}$ climatology. On the contrary, the revised Angstrom exponent retrievals in the UV spectral region increase up to 0.15-0.6 after additional $\mathrm{NO}_{2}$ correction. Both procedures lead to decreasing in the second derivative of logarithm of AOT vs. logarithm of wavelength (Eck et al., 1999) and may affect the inverse RT solution in the AERONET algorithm (Dubovik and King, 2000), especially in case, when $\mathrm{OT}_{\mathrm{NO}_{2}}$ values are close to aerosol optical thickness.

Seasonal variations of $\mathrm{OT}_{\mathrm{NO}_{2}}$ to AOT ratios at different wavelengths are shown in Fig. 5c. One can see that the maximum effect is observed for the ratio at 380 and $440 \mathrm{~nm}$, comprising about $15-20 \%$ in winter and 5-6\% in other seasons. This ratio is smaller at 340 and $500 \mathrm{~nm}$, varying from $10 \%$ in winter to $2-3 \%$ in other seasons. The most substantial changes in aerosol properties and, hence, in solar irradiance due to $\mathrm{NO}_{2}$ correction are observed during the cold period. This implies the increase in the effects of $\mathrm{NO}_{2}$ absorption during winter time.

We estimated relative attenuation due to monthly mean $\mathrm{NO}_{2}$ and aerosol optical thickness for erythemal and long- wave UV $300-380 \mathrm{~nm}$ irradiance at the ground using the TUV model (Madronich and Flocke et al., 1998) with 8stream DISORT solver and pseudo spherical corrections. According to our estimates similar effects of $\mathrm{NO}_{2}$ and AOT of about $4-7 \%$ are observed during winter time, while in summer the effects of AOT reach $14 \%$ compared with 1$2 \%$ due to $\mathrm{NO}_{2}$ (Fig. 5d). There is a pronounced amplification of $\mathrm{NO}_{2}$ effects for longwave UV 300-380 nm irradiance due to the increase of the effective wavelength (from $\sim 305$ $315 \mathrm{~nm}$ for erythemal radiation to $\sim 345 \mathrm{~nm}$ - for UV irradiance $300-380 \mathrm{~nm}$ ), where the $\mathrm{NO}_{2}$ absorption coefficients are much higher. In addition, using the Monte-Carlo model developed in the Institute of Molecular Physics of RRC "Kurchatov Institute" (Rublev et al., 2001), we estimated the effects of $\mathrm{NO}_{2}$ on total shortwave irradiance, which are about $0.5 \%$ in summer and $2.5 \%$ in winter, depending on $\mathrm{NO}_{2}$ content and solar zenith angle.

As a result, we have applied the $\mathrm{NO}_{2}$ correction to monthly mean AOT values for the whole AERONET data set in Moscow since 2001. We should note that large $\mathrm{NO}_{2}$ content can be also observed in forest fire smoke plumes; however, due to large aerosol amount and small $\mathrm{OT}_{\mathrm{NO}_{2}} / \mathrm{AOT}$ ratios, its radiative effect should be small compared with the aerosol radiative impact.

Large $\mathrm{NO}_{2}$ content has also the influence on the retrievals of other aerosol characteristics, which are not considered in this study. However, according to the previous casestudy analysis, we showed the pronounced effects of $\mathrm{NO}_{2}$ on the retrievals of single scattering albedo, which can increase up to 0.02 when the ratio $\mathrm{OT}_{\mathrm{NO}_{2}} / \mathrm{AOT}$ at $440 \mathrm{~nm}$ is about $10 \%$ (Chubarova and Dubovik, 2004). The influence of $\mathrm{NO}_{2}$ on the retrievals of aerosol size distribution is also pronounced with the artificial bias towards smaller particles with overestimating the fine-mode fraction of about $\mathrm{d} V / \mathrm{d} \ln r=0.02 \mu \mathrm{m}^{3} / \mu^{2}$ at $r=0.05-0.065 \mu \mathrm{m}$ and the decrease over $0.01-0.03 \mu \mathrm{m}^{3} \mathrm{~mm}^{-2}$ at $0.11-0.15 \mu \mathrm{m}$ for typical air pollution conditions (Chubarova and Dubovik, 2004). In overall, the fine-mode fraction due to accounting for $\mathrm{NO}_{2}$ content changes on 1-5\%. We should note that in Chubarova and Dubovik, 2004, only a few cases $(n=14)$ were analyzed, while in this study we considered the $\mathrm{NO}_{2}$ effects on AOT climatology over the whole period of measurements. In addition, in Chubarova and Dubovik, 2004 the evaluation of the $\mathrm{NO}_{2}$ content was made using the model vertical profile according to the global 3-D GEOS-CHEM model (Martin et al., 2002), while in this paper we applied the $\mathrm{NO}_{2}$ profile in the low troposphere using the parameterizations obtained according to the in situ $\mathrm{NO}_{2}$ measurements up to $350 \mathrm{~m}$ and a photochemical model directly for Moscow conditions.

A full scheme of aerosol correction for Moscow MSU MO aerosol measurements is shown in Fig. 6. The final aerosol product is attributed to so-called level 2.5 just to be in the mainstream of the AERONET standard level ranks. Currently, the correction has been fulfilled only for the aerosol 


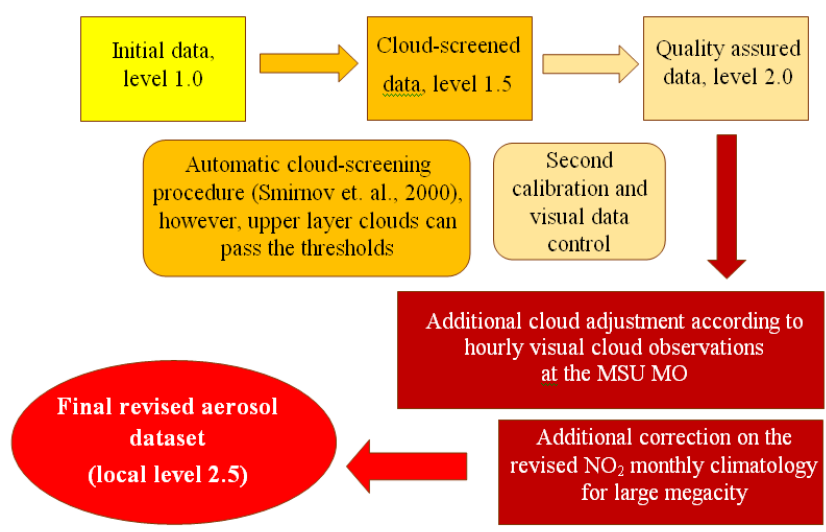

Figure 6. The scheme of the updated AERONET data proceeding with additional cloud adjustment and $\mathrm{NO}_{2}$ correction used at the Moscow MSU MO.

parameters retrieved from direct solar measurements (aerosol optical thickness and Angstrom exponent).

The standard and the revised monthly mean spectral AOT dependences over the 2001-2014 period with the application of the cloud screening and $\mathrm{NO}_{2}$ correction are shown in Fig. 7. The revised spectral dependencies for most months, especially in the cold period, when the $\mathrm{OT}_{\mathrm{NO}_{2}}$ / AOT ratio is high, are characterized by more smooth spectral character due to the influence of spectral $\mathrm{NO}_{2}$ correction. This correction also induces slightly higher determination coefficient when obtaining Angstrom exponent within $440-870 \mathrm{~nm}$ in logarithmic space coordinates. The total difference in annual mean AOT values due to the additional account for cloud screening and $\mathrm{NO}_{2}$ correction is about 0.04 in the UV range, 0.02 in the mid-visible range, and 0.01 in the near-infrared spectral range.

\subsection{Seasonal changes in aerosol optical thickness in Moscow according to the revised data set}

After the additional cloud adjustment and $\mathrm{NO}_{2}$ correction we obtained a revised data set of aerosol optical thickness, water vapor content and Angstrom exponent over the 20012014 period. Figure 8 shows the seasonal changes of monthly mean AOT500, AOT380, and Angstrom exponent $\alpha_{440-870}$ from the revised data set, the data set with only additional cloud screening, and from the standard AERONET level 2.0 data set. The difference between the cloud screening and the revised aerosol optical thickness demonstrates the effect of $\mathrm{NO}_{2}$ additional correction. The revised AOT seasonal cycle is characterized by a pronounced summer maximum reaching $\mathrm{AOT} 500=0.3$ in August, an additional maximum in April (AOT500 $=0.22$ ), and a minimum in December and January $($ AOT500 $=0.08)$. One can see that the application of the additional cloud screening removed a local AOT maximum in February and lowered the December artificial high AOT values. The application of the new $\mathrm{NO}_{2}$ climatology provides the decrease in AOT throughout the year and does not significantly change the AOT seasonal cycle. The maximum effects of $\mathrm{NO}_{2}$ can be seen in the correction of AOT at $380 \mathrm{~nm}$ due to the highest $\mathrm{NO}_{2}$ absorption coefficients. The effects of additional $\mathrm{NO}_{2}$ and cloud screening are comparable for AOT380 and AOT440, while for AOT at other wavelengths the additional cloud screening plays more vital role. The main statistics of the revised AOT, water vapor content and Angstrom exponent are presented in Table 2. It should be noted, that we have very small AOT statistics in December due to high cyclonic activity with cloudy weather. Moreover, the application of the restriction on air mass $m>5$ in the Version 2 data set, which can be observed in December even at noon conditions in Moscow, provides further elimination of case number in the level 2.0 archive. So the obtained climatological values should be taken with caution. However, after the additional corrections, even this small data set demonstrates reasonable AOT values, which are in agreement with the statistics obtained for January (next winter month) conditions (see Table 2).

In Moscow, the Angstrom exponent has a pronounced maximum in summer months, which had been also documented for European conditions (Hsu et al., 2012; Chubarova, 2009). The revised $\alpha_{440-870}$ values are characterized by much more noticeable seasonal dependence with a substantial decrease in December.

Figure 9 presents 3-D distributions of monthly mean, $50 \%$ quantile, maximum and minimum AOT500 values over the 2001-2014 period. The AOT maximum in spring (and, especially, in April) is typical for almost all years and is a characteristic feature for the whole Eastern European plain. It can be explained by the circulation pattern from southeast of Russia and Kazakhstan with dust advection from semideserts and steppes, as well as by the accumulation of the dust after snow melting, and the beginning of agricultural season with the prescribed fires. At the same time, relatively low precipitation prevents wet deposition of aerosol particles and contributes to their accumulation. In April, for example, the precipitation is only $41 \mathrm{~mm}$, which is about $30 \%$ smaller than the annual monthly mean value (Chubarova et al., 2014). The local June minimum is observed due to the increase in precipitation, dominating the northern air advection from Scandinavian regions. This is characterized by more intensive uptake of aerosol by grass and leaves and comparatively high water stored in soil and vegetation, which can also prevent active mineral dust aerosol formation. According to monthly mean data, the summer AOT500 maximum is observed in August. However, AOT500 $50 \%$ quantile has the maximum in July, when the high temperature provides favorable conditions for the second aerosol generation and accumulation of aerosol (see also Fig. 8 and Table 2). The bias towards the fall in monthly mean AOT500 is observed due to the episodes with forest and peat bog fires with high aerosol loading in 2002 (July, August, and September) and 2010 (July, August) (Chubarova et al., 2012). 

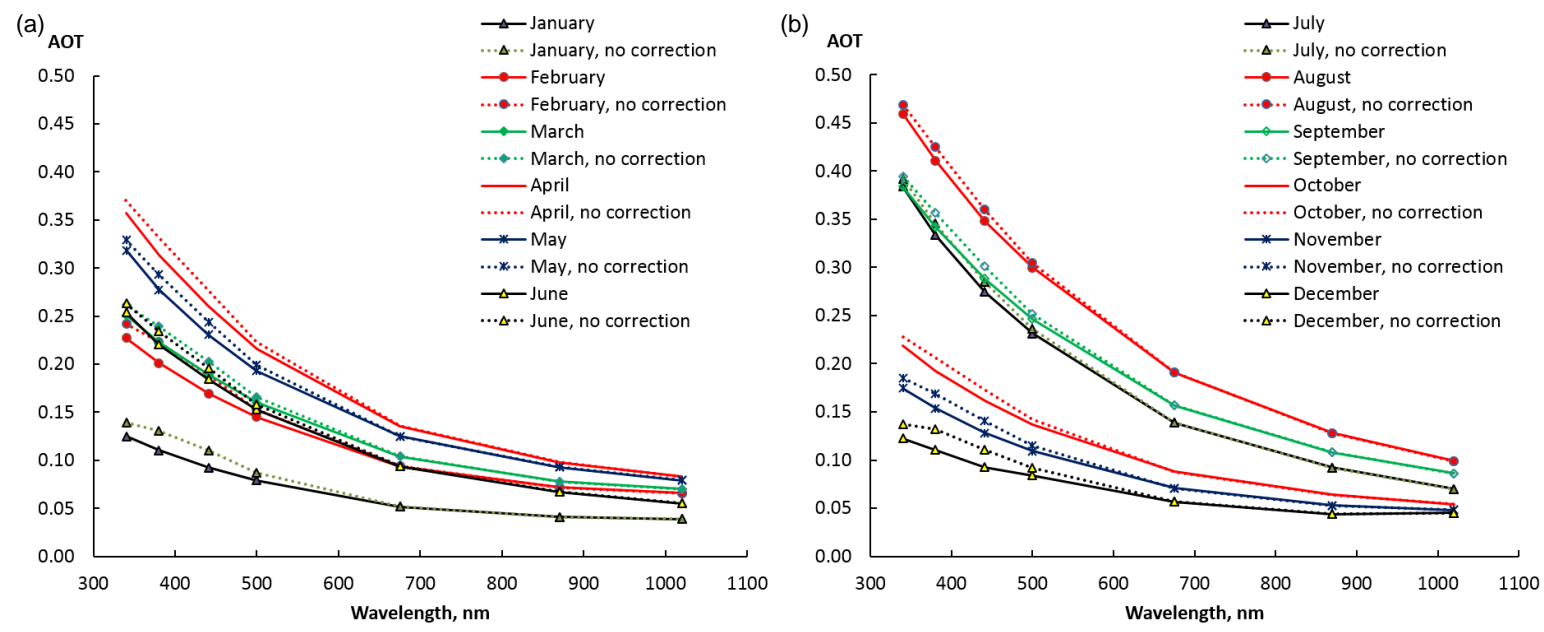

Figure 7. Spectral dependence of monthly mean AOT according to the standard and the revised AERONET data set with the additional cloud screening and $\mathrm{NO}_{2}$ correction (Moscow, 2001-2014).

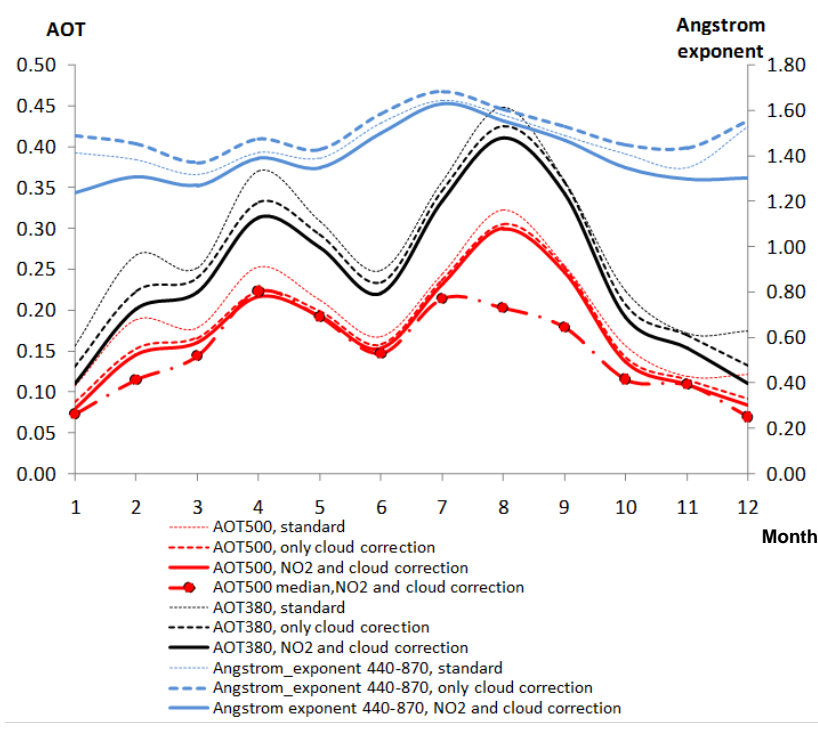

Figure 8. Seasonal variation of monthly mean aerosol optical thickness at 380 and $500 \mathrm{~nm}$, median AOT at $500 \mathrm{~nm}$, and Angstrom exponent according to the standard AERONET level 2.0 data set, the data after the additional cloud screening, and the final revised data set. Note that the additional correction of cloud and $\mathrm{NO}_{2}$ has different sign for Angstrom exponent (Moscow, 2001-2014).

In winter, there is a minimum in AOT due to wet deposition of aerosol during active cyclonic processes and the absence of favorable conditions for second aerosol generation. Note that low AOT in December and February are observed only after $\mathrm{NO}_{2}$ correction and cloud adjustment. Some interesting features can be seen on February 2006 when high average aerosol optical thickness of about AOT500 $=0.31$ and elevated Angstrom exponent were observed due to prevailing fine-mode aerosol effects. We should also mention that the additional cloud screening on February 2006 does not significantly change these aerosol characteristics (the monthly average AOT500 decreases on 0.03 and $\alpha_{440-870}$ value increases on 0.02).

AOT daily maxima are also observed every year in spring and in summer. During the intensive forest fires in Moscow regions in 2002 and 2010 the daily maximum AOT500 has reached 2.3 in July 2002 and 3.7 in August 2010. However, there are no any seasonal changes in daily minima the AOT500 varies within 0.02-0.05 throughout the year. Even during the long-term forest fires episodes, very low and extremely high AOT values are observed during the same month. This phenomenon takes place due to changes in wind direction and the advection of fresh air as well as due to the effective wet deposition of aerosol particles from the atmosphere which, for example, was observed in August 2010.

\subsection{Long-term AOT trends in Moscow and their possible reasons}

The continuous aerosol measurements since 2001 provide a useful tool for studying long-term variability of aerosol properties over 14 years. Table 3 summarizes the correlation coefficients as well as the AOT relative temporal changes for different months, except January and December, when the statistics are too low due to prevailing cloudy conditions. One can see a decrease in monthly mean AOT500 with the rate of about $\sim 1-5 \%$ per year for most months, except June and November. However, the statistically significant trends of mean and daily maxima AOT500 values at $P=95 \%$ are observed only in April, May, and September. After excluding the intensive fire periods in 2002 and 2010, the significance of AOT trend remains the same, but its values have changed, for example, from 10 to $3 \%$ per year in September. In April and September, statistically significant negative trends were 
Table 2. The main statistics of aerosol optical thickness at different wavelengths, water vapor content, and Angstrom exponent $\alpha_{440-870}$ in Moscow. The revised AERONET data set. 2001-2014.

\begin{tabular}{|c|c|c|c|c|c|c|c|c|c|c|c|c|c|}
\hline Months & 1 & 2 & 3 & 4 & 5 & 6 & 7 & 8 & 9 & 10 & 11 & 12 & $\begin{array}{l}\text { Year } \\
\text { average }\end{array}$ \\
\hline $\begin{array}{l}\text { Day } \\
\text { number }\end{array}$ & 33 & 68 & 144 & 191 & 227 & 244 & 290 & 243 & 186 & 87 & 33 & 4 & 146 \\
\hline \multicolumn{14}{|c|}{ Mean } \\
\hline АОТ 340 & 0.12 & 0.23 & 0.25 & 0.36 & 0.32 & 0.25 & 0.38 & 0.46 & 0.38 & 0.22 & 0.17 & 0.12 & 0.27 \\
\hline АОТ 380 & 0.11 & 0.20 & 0.22 & 0.31 & 0.28 & 0.22 & 0.33 & 0.41 & 0.34 & 0.19 & 0.15 & 0.11 & 0.24 \\
\hline AOT440 & 0.09 & 0.17 & 0.19 & 0.26 & 0.23 & 0.18 & 0.27 & 0.35 & 0.29 & 0.16 & 0.13 & 0.09 & 0.20 \\
\hline AOT500 & 0.08 & 0.14 & 0.16 & 0.22 & 0.19 & 0.15 & 0.23 & 0.30 & 0.25 & 0.14 & 0.11 & 0.08 & 0.17 \\
\hline АОТ675 & 0.05 & 0.09 & 0.10 & 0.14 & 0.12 & 0.09 & 0.14 & 0.19 & 0.16 & 0.09 & 0.07 & 0.06 & 0.11 \\
\hline AOT870 & 0.04 & 0.07 & 0.08 & 0.10 & 0.09 & 0.07 & 0.09 & 0.13 & 0.11 & 0.06 & 0.05 & 0.04 & 0.08 \\
\hline AOT 1020 & 0.04 & 0.07 & 0.07 & 0.08 & 0.08 & 0.06 & 0.07 & 0.10 & 0.09 & 0.05 & 0.05 & 0.05 & 0.07 \\
\hline $\begin{array}{l}\text { Water vapor } \\
\text { content, } \mathrm{cm}\end{array}$ & 0.27 & 0.29 & 0.50 & 0.70 & 1.35 & 1.69 & 2.21 & 2.02 & 1.55 & 0.91 & 0.58 & 0.37 & 1.04 \\
\hline $\begin{array}{l}\text { Angstrom } \\
\text { exponent }\end{array}$ & 1.24 & 1.30 & 1.27 & 1.39 & 1.35 & 1.50 & 1.63 & 1.55 & 1.47 & 1.35 & 1.30 & 1.30 & 1.39 \\
\hline \multicolumn{14}{|c|}{ Standard deviation } \\
\hline АОТ 340 & 0.09 & 0.15 & 0.19 & 0.26 & 0.19 & 0.15 & 0.29 & 0.50 & 0.42 & 0.15 & 0.12 & 0.04 & 0.21 \\
\hline АОТ 380 & 0.08 & 0.14 & 0.17 & 0.23 & 0.17 & 0.13 & 0.26 & 0.48 & 0.39 & 0.14 & 0.11 & 0.04 & 0.20 \\
\hline AOT440 & 0.07 & 0.12 & 0.14 & 0.19 & 0.14 & 0.11 & 0.23 & 0.45 & 0.34 & 0.12 & 0.09 & 0.04 & 0.17 \\
\hline AOT500 & 0.06 & 0.10 & 0.12 & 0.15 & 0.11 & 0.09 & 0.19 & 0.41 & 0.30 & 0.10 & 0.07 & 0.04 & 0.14 \\
\hline АОТ675 & 0.04 & 0.07 & 0.08 & 0.09 & 0.07 & 0.05 & 0.12 & 0.29 & 0.19 & 0.06 & 0.05 & 0.04 & 0.09 \\
\hline AOT870 & 0.02 & 0.05 & 0.05 & 0.06 & 0.05 & 0.04 & 0.07 & 0.20 & 0.13 & 0.04 & 0.03 & 0.03 & 0.06 \\
\hline AOT1020 & 0.02 & 0.04 & 0.04 & 0.04 & 0.05 & 0.03 & 0.05 & 0.15 & 0.09 & 0.03 & 0.03 & 0.02 & 0.05 \\
\hline $\begin{array}{l}\text { Water vapor } \\
\text { content, cm }\end{array}$ & 0.12 & 0.09 & 0.25 & 0.28 & 0.56 & 0.54 & 0.50 & 0.53 & 0.47 & 0.41 & 0.28 & 0.14 & 0.35 \\
\hline $\begin{array}{l}\text { Angstrom } \\
\text { exponent }\end{array}$ & 0.24 & 0.28 & 0.29 & 0.23 & 0.29 & 0.25 & 0.17 & 0.18 & 0.21 & 0.24 & 0.16 & 0.35 & 0.24 \\
\hline \multicolumn{14}{|c|}{ Confidence interval $P=95 \%$} \\
\hline AOT340 & 0.03 & 0.04 & 0.03 & 0.04 & 0.02 & 0.02 & 0.03 & 0.06 & 0.06 & 0.03 & 0.04 & 0.04 & 0.04 \\
\hline АОТ 380 & 0.03 & 0.03 & 0.03 & 0.03 & 0.02 & 0.02 & 0.03 & 0.06 & 0.06 & 0.03 & 0.04 & 0.04 & 0.03 \\
\hline AOT440 & 0.02 & 0.03 & 0.02 & 0.03 & 0.02 & 0.01 & 0.03 & 0.06 & 0.05 & 0.02 & 0.03 & 0.04 & 0.03 \\
\hline AOT500 & 0.02 & 0.02 & 0.02 & 0.02 & 0.01 & 0.01 & 0.02 & 0.05 & 0.04 & 0.02 & 0.02 & 0.04 & 0.03 \\
\hline АОТ675 & 0.01 & 0.02 & 0.01 & 0.01 & 0.01 & 0.01 & 0.01 & 0.04 & 0.03 & 0.01 & 0.02 & 0.04 & 0.02 \\
\hline АОТ870 & 0.01 & 0.01 & 0.01 & 0.01 & 0.01 & 0.00 & 0.01 & 0.02 & 0.02 & 0.01 & 0.01 & 0.03 & 0.01 \\
\hline AOT1020 & 0.01 & 0.01 & 0.01 & 0.01 & 0.01 & 0.00 & 0.01 & 0.02 & 0.01 & 0.01 & 0.01 & 0.02 & 0.01 \\
\hline $\begin{array}{l}\text { Water vapor } \\
\text { content, cm }\end{array}$ & 0.04 & 0.02 & 0.04 & 0.04 & 0.07 & 0.07 & 0.06 & 0.07 & 0.07 & 0.09 & 0.10 & 0.14 & 0.07 \\
\hline $\begin{array}{l}\text { Angstrom } \\
\text { exponent, }\end{array}$ & 0.08 & 0.07 & 0.05 & 0.03 & 0.04 & 0.03 & 0.02 & 0.02 & 0.03 & 0.05 & 0.05 & 0.34 & 0.07 \\
\hline \multicolumn{14}{|c|}{$50 \%$ quantile } \\
\hline AOT340 & 0.11 & 0.18 & 0.23 & 0.37 & 0.32 & 0.24 & 0.35 & 0.32 & 0.28 & 0.18 & 0.16 & 0.12 & 0.24 \\
\hline АОТ380 & 0.10 & 0.15 & 0.21 & 0.32 & 0.27 & 0.21 & 0.30 & 0.29 & 0.25 & 0.15 & 0.14 & 0.10 & 0.21 \\
\hline AOT440 & 0.08 & 0.13 & 0.17 & 0.26 & 0.22 & 0.17 & 0.25 & 0.24 & 0.21 & 0.13 & 0.12 & 0.08 & 0.17 \\
\hline AOT500 & 0.07 & 0.11 & 0.14 & 0.22 & 0.19 & 0.15 & 0.21 & 0.20 & 0.18 & 0.12 & 0.11 & 0.07 & 0.15 \\
\hline АОТ675 & 0.05 & 0.08 & 0.09 & 0.14 & 0.12 & 0.09 & 0.13 & 0.13 & 0.11 & 0.07 & 0.07 & 0.04 & 0.09 \\
\hline АОТ870 & 0.04 & 0.06 & 0.07 & 0.10 & 0.09 & 0.07 & 0.09 & 0.08 & 0.08 & 0.05 & 0.05 & 0.03 & 0.07 \\
\hline AOT1020 & 0.04 & 0.06 & 0.06 & 0.08 & 0.07 & 0.06 & 0.07 & 0.07 & 0.06 & 0.04 & 0.05 & 0.04 & 0.06 \\
\hline $\begin{array}{l}\text { Water vapor } \\
\text { content, cm }\end{array}$ & 0.28 & 0.29 & 0.48 & 0.70 & 1.45 & 1.69 & 2.17 & 2.11 & 1.57 & 0.87 & 0.52 & 0.41 & 1.04 \\
\hline $\begin{array}{l}\text { Angstrom } \\
\text { exponent }\end{array}$ & 1.46 & 1.40 & 1.42 & 1.49 & 1.41 & 1.59 & 1.69 & 1.61 & 1.54 & 1.47 & 1.39 & 1.72 & 1.52 \\
\hline \multicolumn{14}{|c|}{ Maximum } \\
\hline AOT340 & 0.37 & 0.62 & 1.10 & 1.52 & 1.37 & 0.87 & 3.19 & 3.79 & 2.90 & 0.77 & 0.70 & 0.20 & 1.45 \\
\hline АОТ 380 & 0.34 & 0.58 & 0.95 & 1.34 & 1.20 & 0.76 & 2.97 & 3.78 & 2.74 & 0.70 & 0.60 & 0.17 & 1.35 \\
\hline AOT440 & 0.30 & 0.51 & 0.79 & 1.10 & 0.96 & 0.66 & 2.60 & 3.63 & 2.46 & 0.57 & 0.48 & 0.16 & 1.18 \\
\hline AOT500 & 0.27 & 0.45 & 0.65 & 0.89 & 0.77 & 0.57 & 2.25 & 3.46 & 2.16 & 0.45 & 0.39 & 0.15 & 1.04 \\
\hline АОТ675 & 0.18 & 0.32 & 0.42 & 0.51 & 0.42 & 0.36 & 1.42 & 2.66 & 1.41 & 0.27 & 0.26 & 0.12 & 0.70 \\
\hline AOT870 & 0.13 & 0.24 & 0.32 & 0.31 & 0.29 & 0.24 & 0.89 & 1.85 & 0.89 & 0.18 & 0.19 & 0.09 & 0.47 \\
\hline АОТ1020 & 0.10 & 0.20 & 0.28 & 0.24 & 0.28 & 0.22 & 0.64 & 1.41 & 0.65 & 0.15 & 0.17 & 0.08 & 0.37 \\
\hline $\begin{array}{l}\text { Water vapor } \\
\text { content, cm }\end{array}$ & 0.60 & 0.52 & 1.39 & 1.80 & 3.11 & 3.16 & 3.46 & 3.53 & 2.82 & 2.11 & 1.29 & 0.55 & 2.03 \\
\hline $\begin{array}{l}\text { Angstrom } \\
\text { exponent }\end{array}$ & 1.86 & 1.89 & 1.86 & 1.93 & 1.98 & 2.12 & 2.11 & 1.94 & 1.96 & 1.88 & 1.72 & 1.82 & 1.92 \\
\hline \multicolumn{14}{|c|}{ Minimum } \\
\hline АОТ340 & 0.03 & 0.05 & 0.06 & 0.04 & 0.08 & 0.05 & 0.10 & 0.08 & 0.07 & 0.07 & 0.05 & 0.11 & 0.07 \\
\hline АОТ 380 & 0.03 & 0.04 & 0.03 & 0.03 & 0.06 & 0.03 & 0.05 & 0.04 & 0.04 & 0.04 & 0.02 & 0.07 & 0.04 \\
\hline AOT440 & 0.02 & 0.03 & 0.03 & 0.03 & 0.05 & 0.03 & 0.05 & 0.04 & 0.03 & 0.03 & 0.02 & 0.05 & 0.04 \\
\hline AOT500 & 0.02 & 0.02 & 0.03 & 0.03 & 0.04 & 0.03 & 0.05 & 0.04 & 0.03 & 0.03 & 0.02 & 0.05 & 0.03 \\
\hline АОТ675 & 0.01 & 0.02 & 0.02 & 0.02 & 0.03 & 0.02 & 0.03 & 0.02 & 0.02 & 0.02 & 0.02 & 0.03 & 0.02 \\
\hline АОТ870 & 0.01 & 0.02 & 0.02 & 0.02 & 0.03 & 0.02 & 0.02 & 0.02 & 0.02 & 0.02 & 0.01 & 0.02 & 0.02 \\
\hline AOT1020 & 0.02 & 0.03 & 0.02 & 0.02 & 0.02 & 0.01 & 0.01 & 0.01 & 0.01 & 0.02 & 0.02 & 0.02 & 0.02 \\
\hline $\begin{array}{l}\text { Water vapor } \\
\text { content, cm }\end{array}$ & 0.07 & 0.11 & 0.16 & 0.20 & 0.50 & 0.64 & 1.12 & 0.90 & 0.53 & 0.24 & 0.21 & 0.16 & 0.40 \\
\hline $\begin{array}{l}\text { Angstrom } \\
\text { exponent }\end{array}$ & 0.96 & 0.72 & 0.56 & 0.82 & 0.42 & 0.43 & 1.04 & 1.02 & 0.44 & 0.86 & 1.01 & 0.96 & 0.77 \\
\hline
\end{tabular}


Table 3. Correlation coefficients and AOT500 trends $\left(\% \mathrm{yr}^{-1}\right)$ over 2001-2014 in monthly mean, 50\% quantile and daily maxima. Statistically significant values at $P=95 \%$ are shown in bold (Moscow).

\begin{tabular}{|c|c|c|c|c|c|c|}
\hline \multirow[t]{2}{*}{ months } & \multicolumn{2}{|c|}{ average } & \multicolumn{2}{|c|}{$50 \%$ quantile } & \multicolumn{2}{|c|}{ daily maxima } \\
\hline & $\begin{array}{l}\text { correlation } \\
\text { coefficient }\end{array}$ & trend, $\% \mathrm{yr}^{-1}$ & $\begin{array}{l}\text { correlation } \\
\text { coefficient }\end{array}$ & trend, $\% \mathrm{yr}^{-1}$ & $\begin{array}{l}\text { correlation } \\
\text { coefficient }\end{array}$ & trend, $\% \mathrm{yr}^{-1}$ \\
\hline 2 & -0.14 & $-2 \%$ & -0.08 & $-1 \%$ & -0.28 & $-4 \%$ \\
\hline 3 & -0.30 & $-3 \%$ & -0.36 & $-4 \%$ & -0.09 & $-1 \%$ \\
\hline 4 & -0.67 & $-5 \%$ & -0.64 & $-7 \%$ & -0.48 & $-4 \%$ \\
\hline 5 & -0.52 & $-2 \%$ & 0.19 & $1 \%$ & -0.69 & $-6 \%$ \\
\hline 6 & -0.04 & $0 \%$ & 0.00 & $0 \%$ & 0.02 & $0 \%$ \\
\hline $7^{\mathrm{a}}$ & $-0.38 /-0.51$ & $-3 \% /-1 \%$ & $-0.10 /-0.14$ & $-1 \% /-1 \%$ & $-0.46 /-0.18$ & $-10 \% /-1 \%$ \\
\hline $8^{\mathrm{a}}$ & $0.01 /-0.47$ & $0 \% /-1 \%$ & $0.03 /-0.19$ & $1 \% /-1 \%$ & $0.04 /-0.14$ & $1 \% /-1 \%$ \\
\hline $9^{a}$ & $-0.50 /-0.50$ & $-10 \% /-3 \%$ & $-\mathbf{0 . 4 8} /-0.43$ & $-10 \% /-3 \%$ & $-0.58 /-0.72$ & $-14 \% /-7 \%$ \\
\hline 10 & -0.05 & $-1 \%$ & -0.08 & $-1 \%$ & -0.04 & $-1 \%$ \\
\hline 11 & 0.09 & $1 \%$ & 0.09 & $1 \%$ & 0.05 & $1 \%$ \\
\hline
\end{tabular}

a - first value corresponds to the whole statistics and the second one - to the statistics without forest fires episodes observed in 2002 and 2010.
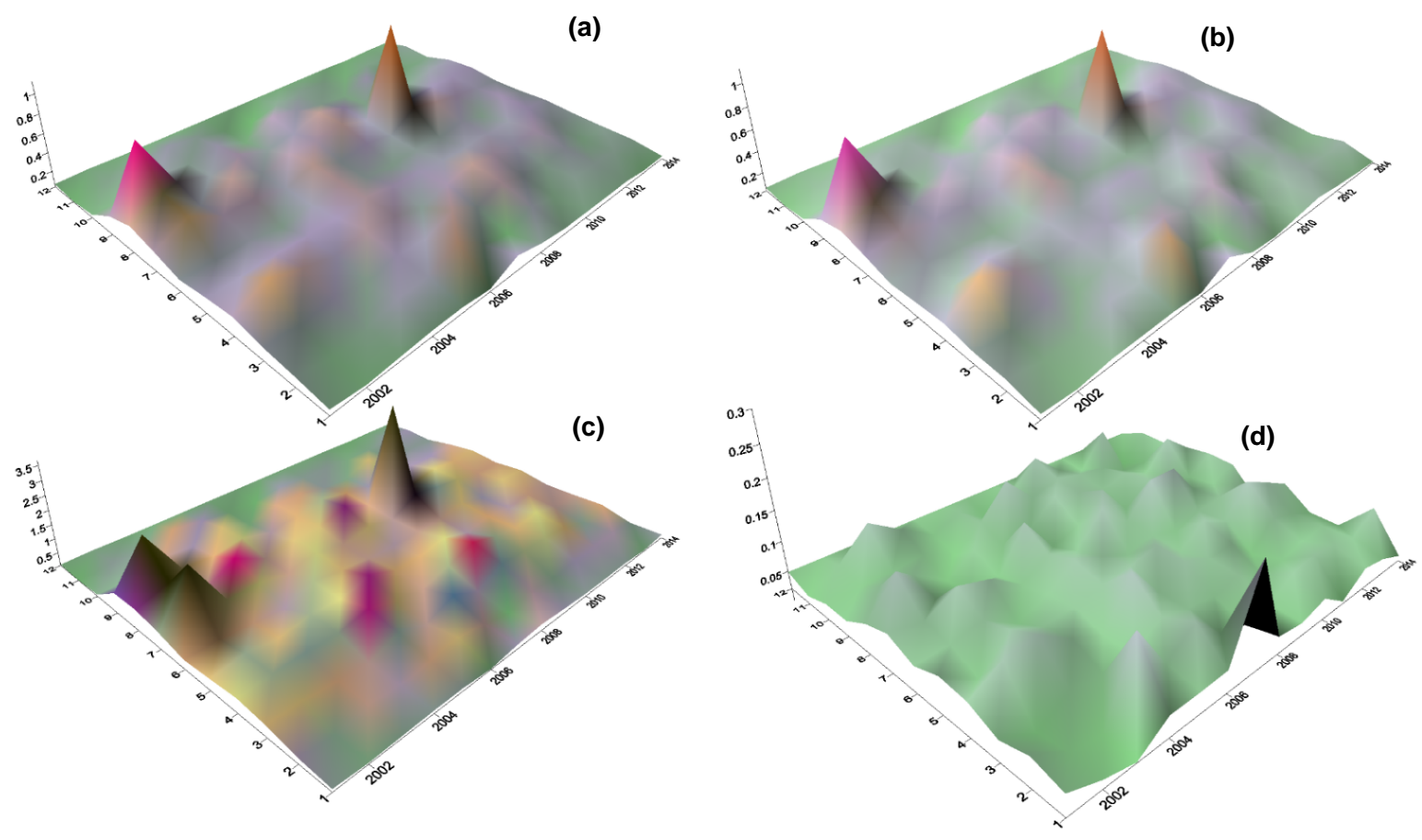

Figure 9. 3-D distribution of the revised monthly mean AOT500 (a); $50 \%$ quantile AOT500 (b); daily AOT500 maximum; (c) and daily AOT500 minimum; (d) (Moscow).

also obtained for $50 \%$ quantile AOT500. Therefore, we can state that the most significant AOT decrease is observed in the spring and fall periods, with prevailing negative tendencies during the whole year.

Relative changes in annual mean and $50 \%$ quantile values of aerosol optical thickness at different wavelengths in the UV, visible and near-infrared spectral ranges are shown in Fig. 10. There are statistically significant negative trends at $P=95 \%$ for annual mean AOT over the whole spectral range with the rate of $-3.4,-3$, and $-2.4 \%$ per year respec- tively in the UV, visible and infrared spectral regions. One can also see a pronounced $15-20 \%$ AOT drop observed in the last 4 years. The statistically significant negative trends at $95 \%$ level are also obtained for annual $50 \%$ quantile AOT at $340,380,440$, and $500 \mathrm{~nm}$ with the rate of about -2.9 to $-2.0 \%$ per year. At the same time, the trends are not statistically significant for $50 \%$ quantile AOT at longer wavelengths (at 675,870 and $1020 \mathrm{~nm}$ ), that could mean the absence of the pronounced temporal changes in coarse mode particles during the whole period of observations in typical 
(a) ${ }_{\mathrm{P} \%}$

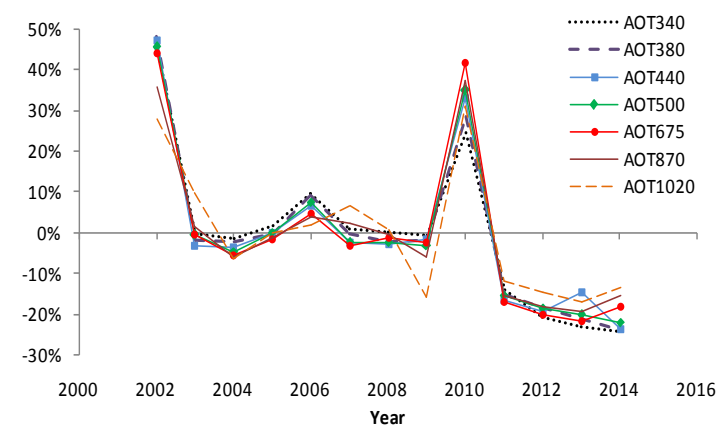

(b) ${ }_{\mathrm{p} \%}$

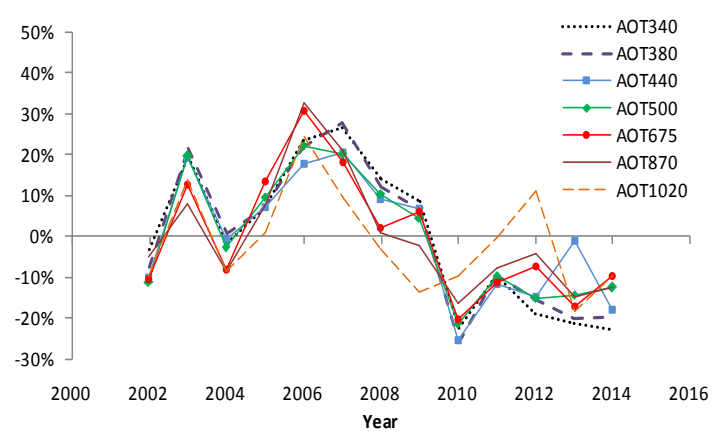

Figure 10. Interannual variations of the revised annual mean (a) and $50 \%$ quantile (b) AOT at several wavelengths (Moscow). Comment: the annual $50 \%$ quantile AOT is estimated from monthly $50 \%$ quantile AOT values. For consistency the 2001 data were not used since the measurements have been in operation only since August.

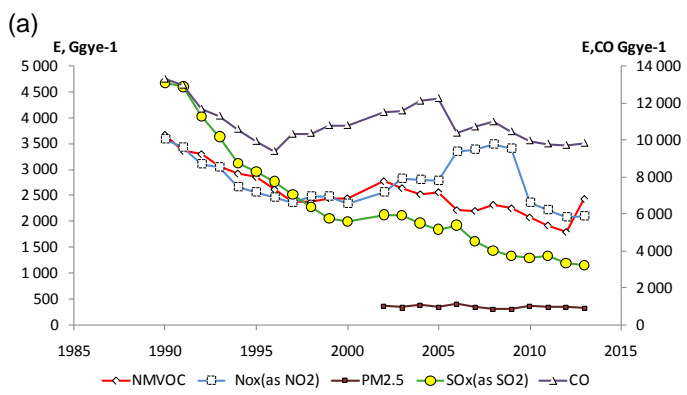

(b)

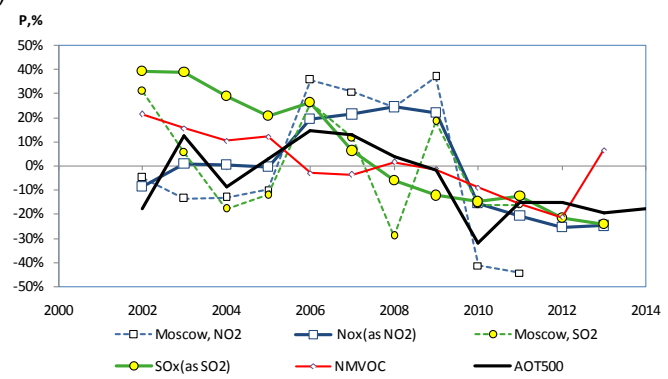

Figure 11. Interannual variations in emissions of main aerosol precursors $\left(\mathrm{SO}_{x}, \mathrm{NO}_{x}, \mathrm{NMVOC}\right), \mathrm{CO}$, and particulate matter $\left(\mathrm{PM}_{2.5}\right)$ according to WebDab - EMEP database over the European part of Russia (a); relative changes in $50 \%$ quantile $\mathrm{AOT} 00$ and in $\mathrm{SO}_{x}$ and $\mathrm{NO}_{x}$ emissions over the European part of Russia and directly over Moscow (b).

conditions, which are better described by the $50 \%$ quantile AOT.

The negative AOT trends in the 21st century are observed over many regions in Europe. For example, according to the satellite data set, Yoon et al. (2014) have revealed a distinct AOT decrease over western Europe of about $-40 \%$ from 2003 to 2008. The same negative trend over 1997 to 2010 in Europe was obtained in Hsu et al., 2012 according to SeaWiFS measurements. In Putaud et al. (2014) the negative trends in AOT and some other aerosol characteristics were also obtained in northern Italy over the 2004-2010 period.

There can be several natural or anthropogenic reasons for these negative AOT trends. In order to study the effect of anthropogenic emissions we used the officially reported emission data from the Centre on Emission Inventories and Projections WebDab - EMEP database (http://www.ceip. at/status_reporting/2014_submissions/). Figure 11a presents temporal variations in emissions of different main aerosol precursors over the European part of Russia, which can affect the secondary aerosol generation in Moscow. One can see a statistically significant at $P=95 \%$ decrease in $\mathrm{SO}_{x}$ emission of about $135 \mathrm{Gg} \mathrm{yr}^{-1}$ per year (or $135 \mathrm{Gg} \mathrm{yr}^{-2}$ ), the negative trend in emission of Non-methane volatile or- ganic compound (NMVOC) of about $54 \mathrm{Gg} \mathrm{yr}^{-2}$. In addition, the $\mathrm{CO}$ emissions, which do not directly influence the secondary aerosol generation but may characterize the intensity of pollution from the transportation sources, also have a pronounced negative trend of about $69 \mathrm{Gg} \mathrm{yr}^{-2}$. This negative trend also confirms the complex character of the atmosphere cleanup. There is also negative change in $\mathrm{NO}_{x}$ emissions over the European part of Russia, especially during recent years, but this decrease is not statistically significant. A very slight negative tendency is observed in emissions of the particulate matter with the diameter less $2.5 \mu \mathrm{m}\left(\mathrm{PM}_{2.5}\right)$. The comparison of temporal variability of main aerosol precursors over the European part of Russia and in Moscow is shown in Fig. 11b. This trend was also present in the annual $50 \%$ quantile AOT500, which is not sensitive to the extremely high aerosol loading during the Moscow 2002 and 2010 fire episodes. One can see the absence of local changes in $\mathrm{SO}_{x}$ in Moscow compared with a distinct negative trend in $\mathrm{SO}_{x}$ up to $-6.5 \%$ a year over the European part of Russia, which can be observed due to changes in fuel from coal to gas. In Moscow this change of fuel was made earlier, at the end of the 1980s. Note also, that the high median AOT values in 2006 correspond well with the elevated emission of 
$\mathrm{SO}_{x}$ both in Moscow and at the whole European part of Russia as well as the elevated emission of $\mathrm{NO}_{x}$ in Moscow. The last years are characterized by a decrease in $\mathrm{NO}_{x}$ emission both in Moscow and in the European part of Russia possibly due to improving the quality of petrol standards. As a result, we assume that the negative trend in AOT is observed likely due to the decrease in anthropogenic emissions of $\mathrm{SO}_{x}$ and NMVOC over the European part of Russia, which play a significant role in second aerosol generation, especially during the warm period. Some important role can also play the decrease in $\mathrm{NO}_{2}$ emission during the last years since 2010.

Natural AOT variations should be also taken into account. For example, since the AOT spatial distribution is characterized by a significant decrease from southeastern to northern Europe (Chubarova, 2009), natural AOT interannual variability can be observed due to the year-to-year variability of different air mass advection. We tested this effect and its possible influence on interannual AOT variability for the months with statistically significant negative trends (April, May, and September). For this purpose we compared the results obtained over the whole period of observations and over the last 5 years since 2010, when low $50 \%$ quantile AOT500 values were observed (see Fig. 10b).

For this purpose we used the Hybrid Single-Particle Lagrangian Integrated Trajectory (HYSPLIT) model (Draxler and Hess, 1998) to generate the $24 \mathrm{~h}$ backward trajectories for the days with AOT measurements at the altitude $H=500 \mathrm{~m}$ for 12:00 UTC. Since Moscow is located close to the center of the European Plain, we combined the results in the standard wind diagram and compared the relative number of cases in different directions over the whole period of measurements (2002-2014) with that over the last years (20102014). We will consider that the significant difference in circulation pattern occurs, when the change in relative number of cases over a particular direction exceeds $5 \%$. In addition, we calculated the daily mean AOT500 for the air masses coming from different directions. Figure 12 presents the obtained wind diagrams as well as the mean daily AOT500 diagrams over these two periods. One can see that in most cases there is no significant difference in wind diagrams between 2010-2014 and 2002-2014 periods for all 3 months. The exception was observed in May with small prevailing of air mass advection from the east $(+7 \%)$, accompanied by slightly lower AOT (difference in AOT500 $=-0.02$ ), and in September with small prevalence of the air mass advection from the north $(+6 \%)$ accompanied by slightly higher AOT values (difference in AOT500 $=+0.03$ ). The increase in AOT500 higher than 0.01 was observed only in conditions with south-west air mass advection, which were infrequent, in April (difference in AOT500 $=+0.09$ ), and in September in conditions with north and east air mass advection (difference in AOT500 $=+0.03$ ). Lower AOT500 values during the last 2010-2014 period were observed almost at all the directions of air mass advection with the difference of about 0.02/0.14 in April, 0.02/0.10 in May and 0.03/0.18 in
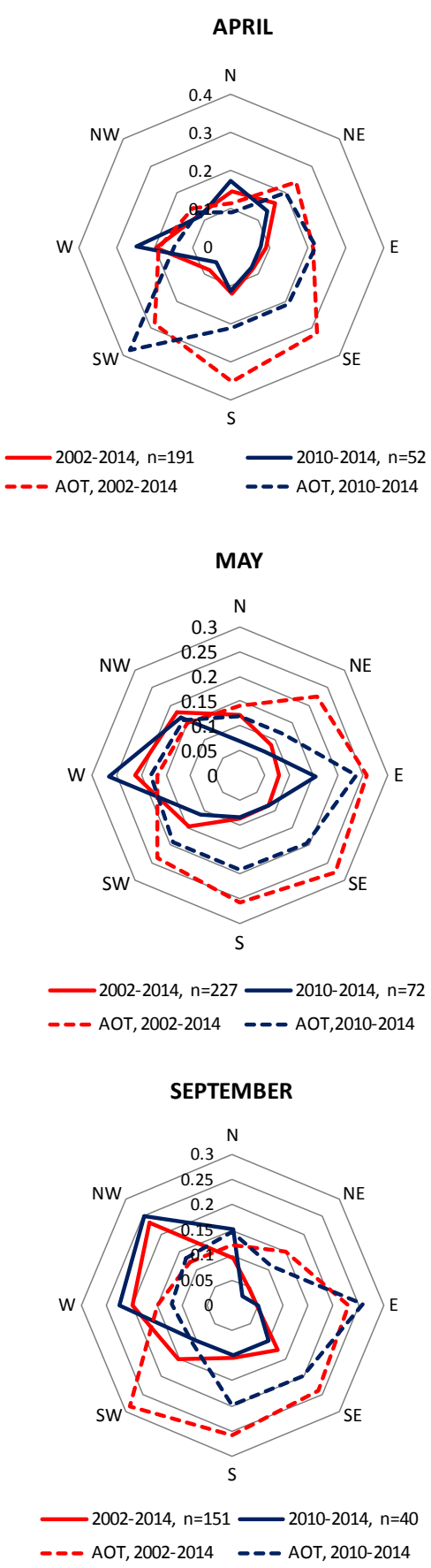

Figure 12. The wind diagram (in unit fraction) over the whole period of observations (2002-2014) and over the 2010-2014 period (solid lines) and distribution of AOT500 at different wind directions over the same periods (dashed line) (in AOT units) for the months with statistically significant negative trends. Wind directions were obtained according to the NOAA HYSPLIT model $24 \mathrm{~h}$ backward trajectory analysis at $500 \mathrm{~m}$ a.g.1. for 12:00 UTC.

September. Hence, we can state that there were no significant changes in circulation pattern during the last years, and the negative change in AOT was observed almost at all di- 
rections. Note that the data from September 2002, when the intensive forest fires were observed and AOT500 was unusually high, were not used in this analysis.

Wet aerosol deposition, regulated by precipitation, can also play an important role in year-to-year AOT variability. In addition, the enhancement of the dynamic stability of the atmosphere can be an effective factor leading to the stagnation of air and, hence, to the aerosol accumulation. As a parameter characterizing the atmospheric instability we used the convective available potential energy (CAPE) (Barry and Chorley, 1998). The CAPE data from the ERA-Interim re-analysis over Moscow $\left(36-38^{\circ} \mathrm{E}, 55-56^{\circ} \mathrm{N}\right)$ were taken for the days, when the aerosol measurements were made. As a result, multiple regression analysis has been applied for studying the relationship of monthly mean AOT500 with temperature (as an indicator of air advection), precipitation, wind speed, wind direction and CAPE characteristics according to the Moscow data set over the whole period of measurements. However, the analysis revealed the absence of any significant AOT correlation with any of the characteristics considered. This means that natural factors might not be responsible for the negative AOT trend in the Moscow area.

In addition, we compared the changes of meteorological parameters, AOT500, the annual emissions of main aerosol precursors and $\mathrm{PM}_{2.5}$, observed during the last 2010-2014 period with their values for the whole data set 2002-2014. We have to analyze the existing 2002-2013 data set for emissions and assume, that they do not vary within the year, since the monthly resolution data are not available. All data were normalized against their means. Figure 13 shows error bars interval of relatively changes in monthly mean AOT500, air temperature, precipitation, CAPE, as well as NMVOC, $\mathrm{NO}_{x}$, $\mathrm{PM}_{2.5}, \mathrm{SO}_{x}$ emissions over the whole period of observations since 2002 at the confidence level $P=95 \%$ and, for comparison, their 2010-2014 mean relative changes against the whole period of observations for April, May, and September. One can see that the mean negative changes in emissions during the last 2010-2013 years are significantly higher than error bars interval over the whole period, while the relative changes in meteorological factors demonstrate different signs, except the precipitation, which slightly increases during all months. Their mean relative changes lie mainly within the error bars interval at $P=95 \%$, except air temperature in May, and CAPE in September. However, for the other months, these parameters have even the opposite sign, which might indicate that their respective changes are random in nature.

Hence, we should state that the effect of the negative trends in emissions likely are the main influence on the negative AOT500 trend that was observed over Moscow. There are some slight changes in meteorological regime and advection, but they are not significant.
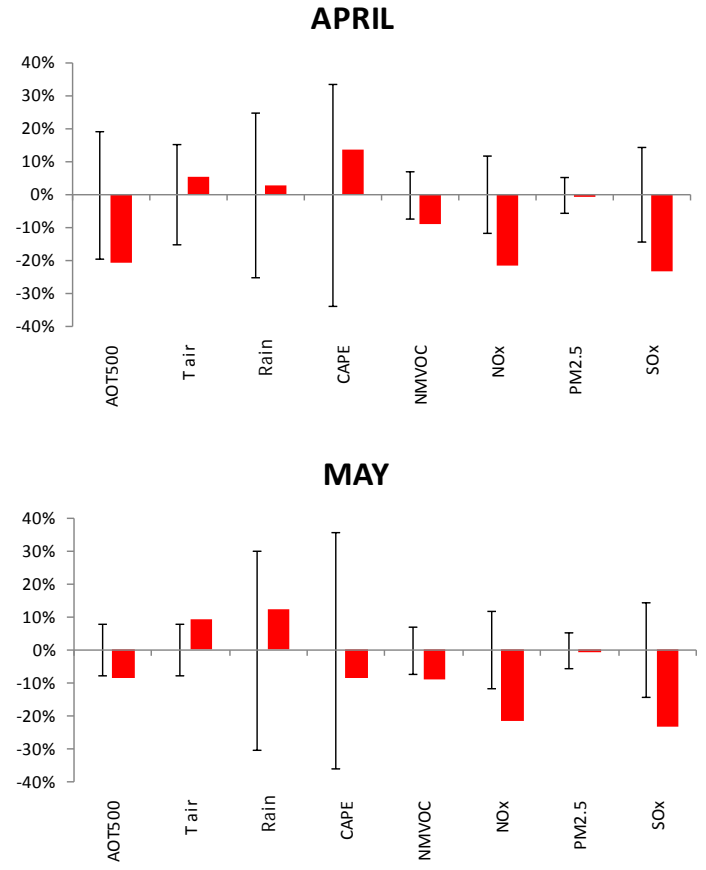

SEPTEMBER

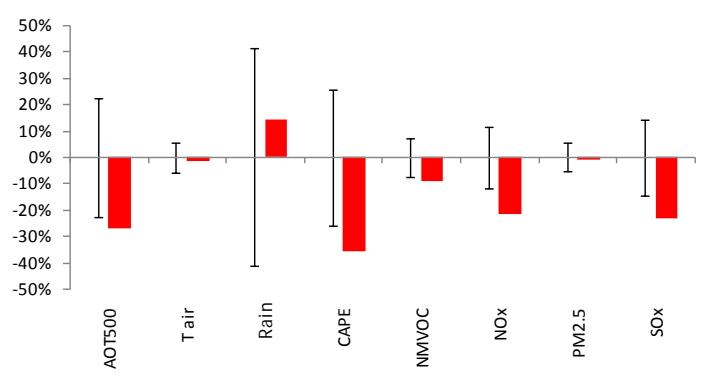

Figure 13. Error bars interval at confidence level $P=95 \%$ of relatively change in monthly mean AOT500, air temperature (Tair), precipitation (rain), CAPE, as well as different emissions (NMVOC, $\mathrm{NO}_{x}, \mathrm{PM}_{2.5}, \mathrm{SO}_{x}$ ) from the WebDab - EMEP database and mean relative changes of these characteristics over 2010-2014. All the data were normalized against their mean values over the whole period of observation. For homogeneity reasons, we do not include September 2002 in the analysis due to the large effect of smoke aerosol from forest fires, and April 2012, since it was a problem with sun photometer records. Note that the emissions data are available only up to 2013 .

\section{Discussion}

We propose the additional cloud-screening adjustment and the correction for the revised $\mathrm{NO}_{2}$ content in large megacity conditions for obtaining the highest quality data set of aerosol properties. Small but systematical AOT500 overestimation up to 0.03 in the standard AERONET data set was received due to the effects of optically thin, homogeneous clouds. This overestimation is usually higher than the uncer- 
tainty of AOT measurements. However, in some months, the application of additional cloud filter resulted in an AOT bias of more than 0.1 .

We should mention that there could be some other physical processes (new particle formation, aerosol humidification growth) responsible for the possible AOT increase in cloudy conditions, which were described in several recent publications (Quaas et al., 2010; Eck et al., 2014). As a result, considering the aerosol climatology, two competing phenomena can be observed: the effects of cloud contamination on aerosol properties and the possible changes in aerosol properties in the vicinity of clouds. We should note that since it is not possible to differentiate between these two processes without special field experiments, for example, in Eck et al., 2014, our revised aerosol climatology relates to the classical way of aerosol properties evaluation, when cloudcontaminated cases are removed from the sample, and possible AOT increase in the vicinity of clouds is not accounted for. The application of the additional cloud filter allowed for the removal of cloud-contaminated cases, when solar disk was obscured by clouds almost in all cases, except $0.5 \%$ in winter, which provides a better quality aerosol data set.

The relative AOT500 difference between the standard data set and the data set with the additional cloud screening has minimum in summer (5\%) and maximum up to $20-30 \%$ for winter months when the occurrence of optically thin, homogeneous cloudiness is high, and AOT values are low. The larger AOT difference in winter can also be attributed to more cloud filtering (with strict filter of human observed cloud fraction $\geq 60 \%$ ) and therefore highly likely larger differences with the standard AERONET values.

The application of an additional cloud filter results in significantly decrease in day number up to 7-20\% during the warm period, and $25-45 \%$ during the cold period because of higher occurrence of overcast upper layer cloudiness and the application of more strict filter NA $<6$. We should also note that the susceptibility percentage of contaminated cases is in the qualitative agreement with the data shown in Chew et al. (2011) as well as with the results obtained in Huang et al., 2012 for the collocated AERONET/CALIPSO and AERONET/MODIS measurements.

Since the effects of the proposed additional cloud screening are important, its application may help in obtaining the better quality aerosol data sets by different users, especially for the old, historical records. However, we admit that this is not a rigorous assessment. But this additional correction could be very useful in different applications. It is also possible to verify the current aerosol data sets using the cloud data from the automatic total sky imagers, which have been already in operation at several sites (O'Neill et al., 2003; Jeong and $\mathrm{Li}, 2010$ ) or using the collocated lidar measurements (Chew et al., 2011; Huang et al., 2012).

For additional $\mathrm{NO}_{2}$ correction, a new $\mathrm{NO}_{2}$ content climatology over Moscow has been applied according to the algorithm, which has been developed recently (Chubarova et al.,
2010) on the base of in situ $\mathrm{NO}_{2}$ concentration measurements at different altitudes and the results of photochemical model. The new monthly mean $\mathrm{NO}_{2}$ content is $2-3$ times higher than that in the AERONET data set, which is used for the aerosol correction due to extremely large $\mathrm{NO}_{x}$ emission in large megacity, like Moscow. The most pronounced effects of $\mathrm{OT}_{\mathrm{NO}_{2}}=0.02-0.03$ are observed at 380 and $440 \mathrm{~nm}$ channels due to the strongest $\mathrm{NO}_{2}$ absorption. The obtained monthly mean $\mathrm{NO}_{2}$ climatology can be considered to be a typical one for megalopolis conditions with 12 million residents and the $\mathrm{NO}_{x}$ emission rates of about $100 \mathrm{kt} \mathrm{yr}^{-1}$ (Ivanov et al., 2012). The $\mathrm{NO}_{2}$ correction over other megacities can also be made according to long-term satellite $\mathrm{NO}_{2}$ retrievals but after their rigorous validation. It should be emphasized that the upcoming AERONET Version 3 database utilizes a new monthly mean climatology of total columnar $\mathrm{NO}_{2}$ from the OMI satellite sensor data and that these values are significantly higher than those obtained from the SCIAMACHY database for the Moscow_MSU_MO site (T. Eck, personal communication, 2015).

Seasonal changes of $\mathrm{OT}_{\mathrm{NO}_{2}}$ to AOT ratio at 380 and $440 \mathrm{~nm}$ vary from $15-20 \%$ in winter to $5-6 \%$ in the warm period. This ratio is much smaller at 340 and $500 \mathrm{~nm}$, changing from $10 \%$ in winter to $2-3 \%$ in the warm period. Hence, the most substantial changes in aerosol properties and, hence, in solar irradiance due to $\mathrm{NO}_{2}$ correction would be observed during the cold period. According to radiative modeling this results in similar effects of $\mathrm{NO}_{2}$ and aerosol of about 4-7\% in winter in the UV spectral region. For shortwave irradiance the $\mathrm{NO}_{2}$ effect in Moscow changes within $0.5-2.5 \%$ and also increases in winter.

The total difference in annual mean AOT values due to the additional account for cloud adjustment and $\mathrm{NO}_{2}$ correction is about 0.04 in the UV, 0.02 in mid-visible, and 0.01 in near-infrared spectral ranges. Note that the $\mathrm{NO}_{2}$ correction mainly concerns the $340,380,440$, and $500 \mathrm{~nm}$ AOT channels and the retrievals of Angstrom exponent. The revised aerosol product after the application of additional cloud and $\mathrm{NO}_{2}$ correction is attributed to so-called level 2.5 to be in the mainstream of the AERONET standard level ranks. Currently, the correction has been fulfilled only for the aerosol parameters retrieved from direct solar measurements (aerosol optical thickness, Angstrom exponent, and water vapor content).

The revised data set of monthly mean aerosol optical thickness and Angstrom exponent in Moscow was used for studying seasonal changes as well as AOT long-term variability over the 2001-2014 period.

The corrected AOT mean seasonal cycle is characterized by a pronounced summer maximum, an additional spring maximum, and a minimum in winter conditions (DecemberJanuary). The application of the additional cloud screening removes a local AOT maximum in February, and lowered the December artificial high AOT values. Although we have only a 4-day sample for December, the application of addi- 
tional correction provides reasonable changes removing the cloud-contaminated cases with high optical thickness. However, still due to small statistics, the results for this month should be taken with caution. After the application of additional filters, we also obtained a much more noticeable seasonal dependence of Angstrom exponent with the maximum during summer period.

There are pronounced, statistically significant negative trends at $P=95 \%$ in temporal variation of mean and $50 \%$ quantile AOT500 values for some months over 2001-2014. We also found a decrease in monthly mean AOT500 changes of about $-1-5 \%$ per year for most months; however, the statistically significant trends of mean and daily maxima AOT500 values are observed in April, May, and September. The most significant temporal changes in AOT are observed in the spring and fall periods. This is especially important since April is characterized by local seasonal AOT maximum. Removal of AOT observed during the intensive fire periods in 2002 and 2010 does not change the significance of the results, but modify the value of AOT500 relative change.

There are also statistically significant negative trends at $P=95 \%$ in annual mean AOT variations over the whole spectral range with higher relative changes at UV and visible wavelengths compared with near-infrared region. At the same time, considering annual $50 \%$ quantile AOT variations we found statistically significant negative trends in AOT only in the UV and mid-visible spectral ranges. The absence of statistically significant trend in the $50 \%$ quantile of AOT at longer wavelengths $(675,870$ and $1020 \mathrm{~nm})$ could mean the absence of significant temporal changes in coarse mode particles during the whole period of observations in typical conditions, which are better described by the analysis of $50 \%$ quantile AOT. During the last 4 years, a pronounced 15-20\% decrease in AOT is observed both for mean and $50 \%$ quantile values in the UV and mid-visible ranges.

To understand the cause of the negative trends we used the officially reported emission data from WebDab EMEP database (http://www.ceip.at/status_reporting/2014_ submissions/). According to these data, we showed that the decrease in AOT in 21 century can be observed due to statistically significant at $P=95 \%$ negative trends in $\mathrm{SO}_{x}$ emission of about $135 \mathrm{Gg} \mathrm{yr}^{-2}$, in NMVOC emission of about $54 \mathrm{Gg} \mathrm{yr}^{-2}$, which can affect the secondary aerosol generation. We found that the high median AOT values in 2006 correspond well with the elevated emission of $\mathrm{SO}_{x}$ both in Moscow and at the European part of Russia, as well as with $\mathrm{NO}_{x}$ - in Moscow. The last years are characterized by the decrease in $\mathrm{NO}_{x}$ emission both in Moscow and at the European part of Russia possibly due to improving the quality of petrol standard. However, the $\mathrm{NO}_{2}$ trend in Moscow and over the European part of Russia is not statistically significant.

We also studied the possible effect of natural factors on the interannual AOT variability. According to the $24 \mathrm{~h}$ NOAA HYSPLIT model backward trajectory analysis at $500 \mathrm{~m}$ a.g.l. for 12:00 UTC, we obtained the wind diagrams and the distri- bution of daily AOT500 at different directions of the air mass advection for the months with statistically significant negative AOT trends (April, May, September). However, no significant difference in wind diagram is observed over 2010 2014 compared with the 2002-2014 period for all 3 months except the small increase $(+7 \%)$ in conditions with the east air mass advection, accompanied by slightly smaller AOT in May, and the small increase $(+6 \%)$ of air mass advection from the north with slightly higher AOT values in September. At the same time, we see a significant drop in AOT500 values almost at all directions, except south-west air mass advection in April, which occurrence is small, and in conditions with north and east air advection in September.

No statistically significant correlation was obtained in monthly mean AOT relationship with different meteorological parameters and CAPE. The analysis of relative changes in different characteristics obtained during the last years against the whole period of observations has revealed that mean negative changes in emissions of aerosol precursors over the 2010-2013 period were significantly higher than those over the whole period, while the relative changes in meteorological factors demonstrate different signs, except the precipitation, which slightly increased in all months. However, its changes are not statistically significant. This means the importance of the anthropogenic factor (negative emissions of aerosol precursors) for attributing the negative AOT trend in Moscow.

\section{Conclusions}

We have shown the necessity of additional cloud screening and $\mathrm{NO}_{2}$ correction for retrieving the best quality aerosol climatology in the AERONET version 2 data set. The application of the additional cloud-screening filters revealed a noticeable positive bias of up to 0.03 in monthly mean aerosol optical thickness compared with the results obtained from the standard algorithm.

A new $\mathrm{NO}_{2}$ climatology over Moscow has been obtained. Its application demonstrates that tropospheric $\mathrm{NO}_{2}$ content in Moscow is 2-3 times larger than that applied in the standard AERONET algorithm. The additional $\mathrm{NO}_{2}$ correction of aerosol optical thickness is about 0.01 at $340 \mathrm{~nm}$, and 0.015 - at 380 and $440 \mathrm{~nm}$.

The total difference in annual mean AOT values due to the additional account for cloud screening and $\mathrm{NO}_{2}$ correction is about 0.04 in the UV, 0.02 in mid-visible, and 0.01 in near-infrared spectral ranges, which are higher than the uncertainty of AOT measurements. The $\mathrm{NO}_{2}$ correction mainly concerns the $340,380,440$, and $500 \mathrm{~nm}$ AOT channels and the retrievals of Angstrom exponent.

The revised data set was used for the analysis of seasonal and year-to-year variability of aerosol optical thickness in Moscow over the 2001-2014 period. We have revealed the distinct seasonal cycle in AOT500 values changing from 0.08 
in December up to 0.3 in August as well as summer maximum in Angstrom exponent.

The interannual changes in aerosol properties reveal distinct, statistically significant, negative annual trends, especially for AOT in the UV and mid-visible spectral ranges with the AOT drop of about $15-20 \%$ in the last 4 years. Negative AOT trends are also statistically significant in April, May, and September. We show that the main reason for the AOT decrease could be negative trends in emissions of different aerosol precursors over the European Plain according to the WebDab - EMEP database. We showed that the AOT negative trend can be observed due to a noticeable decrease in $\mathrm{SO}_{x}, \mathrm{NMVOC}$ emissions at the European Plain as well as due to the additional decrease in $\mathrm{NO}_{x}$ during the last years. The analysis of variability in natural factors has not revealed their significant influence on negative AOT trends. However, further studies will be helpful for understanding the role of specific emissions and their interaction with changing weather conditions.

Acknowledgements. We would like to thank the anonymous reviewer and Thomas Eck for very helpful comments as well as Alexander Smirnov (NASA Goddard Space Flight Center) for fruitful discussions. The authors gratefully acknowledge the NOAA Air Resources Laboratory (ARL) for the provision of the HYSPLIT transport and dispersion model and READY website (http://www.ready.noaa.gov) used in this publication. The work was partially supported by RFBR grants \#16-05-00985 and \#15-05-03612.

Edited by: O. Torres

\section{References}

Barry, R. G. and Chorley, R. J.: Atmosphere, weather and climate (7th ed.), Routledge, London, UK, 80-81, 1998.

Brasseur, G. and Solomon S.: Aeronomy of the Middle Atmosphere, D. Reidel Publishing company, Dordrecht, the Netherlands, 452 pp., 1986.

Bruns, M.: NO2 retrieval using Airborne Multi Axis Differential Optical Absorption Spectrometer (AMAXDOAS) data, Dissertation, Universität Bremen, Germany, 174 pp., 2004.

Bruns, M., Buehler, S. A., Burrows, J. P., Richter, A., Rozanov, A., Wang, P., Heue, K. P., Platt, U., Pundt, I., and Wagner, T.: $\mathrm{NO}_{2}$ Profile retrieval using airborne multi axis UV-visible skylight absorption measurements over central Europe, Atmos. Chem. Phys., 6, 3049-3058, doi:10.5194/acp-6-3049-2006, 2006.

Chew, B. N., Campbell J. R., Reid J. S., Giles D. M., and Welton E. J.: Salinas S.V., and Liew S.C.: Tropical cirrus cloud contamination in sun photometer data, Atmos. Environ., 45, 6724-6731, 2011.

Chubarova, N. and Dubovik, O.: The sensitivity of aerosol properties retrievals from AERONET measurements to $\mathrm{NO}_{2}$ concentration over industrial region on the example of Moscow, Optica Pura y Aplicada, A. Hidalgo (Spain), 37, 3315-3319, 2004.
Chubarova, N., Nezval', Ye., Sviridenkov, I., Smirnov, A., and Slutsker, I.: Smoke aerosol and its radiative effects during extreme fire event over Central Russia in summer 2010, Atmos. Meas. Tech., 5, 557-568, doi:10.5194/amt-5-557-2012, 2012.

Chubarova, N. E., Larin, I. K., and Lezina, E. A.: Experimental studies and modeling of nitrogen dioxide variations in the lowest troposphere layer in Moscow , Newsletter Moscow State University, series 5, Geography, 5, 11-18, 2010.

Chubarova, N. E., Nezval', E. I., Belikov, I. B., Gorbarenko, E. V., Eremina, I. D., Zhdanova, E. Yu, Korneva, I. A., Konstantinov, P. I., Lokoshchenko, M. A., Skorokhod, A. I., and Shilovtseva O. A.: Climatic and environmental characteristics of Moscow megalopolis according to the data of the Moscow State University Meteorological Observatory over 60 years Russian Meteorology and Hydrology, Allerton Press Inc., New York, USA, 39, 602-613, 2014.

Chubarova, N. Y.: Seasonal distribution of aerosol properties over Europe and their impact on UV irradiance, Atmos. Meas. Tech., 2, 593-608, doi:10.5194/amt-2-593-2009, 2009.

Chubarova, N. Y., Larin, I. K., Lebedev, V. V., Partola, V., Lezina, E. A., and Rublev A. N.: Experimental and Model Study of Changes in Spectral Solar Irradiance in the Atmosphere of Large City due to Tropospheric $\mathrm{NO}_{2}$ Content, Current Problems in Atmospheric Radiation, Proceedings of the International Radiation Symposium (IRC/IAMAS), AIP Conference Proceedings 1100 , 459-462, doi:10.1063/1.3117019, 2009.

Chubarova, N. Y., Sviridenkov, M. A., Smirnov, A., and Holben, B. N.: Assessments of urban aerosol pollution in Moscow and its radiative effects, Atmos. Meas. Tech., 4, 367-378, doi:10.5194/amt-4-367-2011, 2011.

Draxler, R. R. and Hess G. D.: An overview of the HYSPLIT_4 modeling system of trajectories, dispersion, and deposition, Aust. Meteorol. Mag., 47, 295-308, 1998.

Dubovik, O. and King, M. D.: A flexible inversion algorithm for retrieval of aerosol optical properties from Sun and sky radiance measurements, J. Geophys. Res., 105, 20673-20696, 2000.

Eck, T. F., Holben, B. N., Reid, J. S., Dubovik, O., Smirnov, A., O'Neill, N. T., Slutsker, I., and Kinne, S.: Wavelength dependence of the optical depth of biomass burning, urban and desert dust aerosols, J. Geophys. Res., 104, 31333-31349, 1999.

Eck, T. F., Holben, B. N., Reid, J. S., Giles, D. M., Rivas, M.A., Singh, R. P., Tripathi, S. N., Bruegge, C. J., Platnick, S.,Arnold, G. T., Krotkov, N. A., Carn, S. A., Sinyuk, A., Dubovik, O., Arola, A., Schafer, J. S., Artaxo, P., Smirnov, A., Chen, H., and Goloub, P.: Fog- and cloud-induced aerosol modification observed by the Aerosol Robotic Network (AERONET), J. Geophys. Res., 117, D07206, doi:10.1029/2011JD016839, 2012.

Eck, T. F., Holben, B. N., Reid, J. S., Arola, A., Ferrare, R. A., Hostetler, C. A., Crumeyrolle, S. N., Berkoff, T. A., Welton, E. J., Lolli, S., Lyapustin, A., Wang, Y., Schafer, J. S., Giles, D. M., Anderson, B. E., Thornhill, K. L., Minnis, P., Pickering, K. E., Loughner, C. P., Smirnov, A., and Sinyuk, A.: Observations of rapid aerosol optical depth enhancements in the vicinity of polluted cumulus clouds, Atmos. Chem. Phys., 14, 11633-11656, doi:10.5194/acp-14-11633-2014, 2014.

Elansky, N. F., Lokoshchenko, M. A., Belikov, I. B., Skorokhod, A. I., and Shumskii, R. A.: Variability of trace gases in the atmospheric surface layer from observations in the city of Moscow, Izvestiya, Atmospheric and Oceanic Physics, 43, 219-231, 2007. 
Eskes, H. J. and Boersma, K. F.: Averaging kernels for DOAS totalcolumn satellite retrievals, Atmos. Chem. Phys., 3, 1285-1291, doi:10.5194/acp-3-1285-2003, 2003.

Evnevich, T. V. and Savikovskij, I. A.: Calculation of direct solar radiation and coefficient of atmospheric transparency, Meteorol. Gydrol., 5, 106-109, 1989.

Heland, J., Schlager, H., Richter, A., and Burrows J. P.: First comparison of tropospheric $\mathrm{NO}_{2}$ column densities retrieved from GOME measurements and in situ aircraft profile measurements, Geophys. Res. Lett., 29, 1983, doi:10.1029/2002GL015528, 2002

Hilboll, A., Richter, A., and Burrows, J. P.: Long-term changes of tropospheric $\mathrm{NO}_{2}$ over megacities derived from multiple satellite instruments, Atmos. Chem. Phys., 13, 4145-4169, doi:10.5194/acp-13-4145-2013, 2013.

Holben, B. N., Eck, T. F., Slutsker, I., Tanre, D., Buis, J. P., Setzer, A., Vermote, E., Reagan, J. A., Kaufman, Y. J., Nakajima, T., Lavenu, F., Jankowiak, I., and Smirnov, A.: AERONET - A federated instrument network and data archive for aerosol characterization, Remote Sens. Environ., 66, 1-16, 1998.

Holben, B. N.,Tanre, D., Smirnov, A., Eck, T. F., Slutsker, I., Abuhassan, N., Newcomb, W. W., Schafer, J., Chatenet, B., Lavenue, F., Kaufman, Y. J., Vande Castle, J., Setzer, A., Markham, B., Clark, D., Frouin, R., Halthore, R., Karnieli, A., O’Neill, N. T., Pietras, C., Pinker, R. T., Voss, K., and Zibordi, G.: An emerging ground-based aerosol climatology: Aerosol Optical Depth from AERONET, J. Geophys. Res., 106, 12067-12097, 2001.

Holben, B. N., Eck, T., Slutsker, I., Smirnov, A., Sinyuk, A., Schafer, J., Giles, D., and Dubovik, O.: AERONET Version 2.0 quality assurance criteria, in: Remote Sensing of the Atmosphere and Clouds, edited by: Tsay, S.-C., Nakajima, T., Singh, R. P., and Sridharan, R., Proc. of SPIE, Goa, India, 13-17 November, 6408, 2006.

Hsu, N. C., Gautam, R., Sayer, A. M., Bettenhausen, C., Li, C., Jeong, M. J., Tsay, S.-C., and Holben, B. N.: Global and regional trends of aerosol optical depth over land and ocean using SeaWiFS measurements from 1997 to 2010, Atmos. Chem. Phys., 12, 8037-8053, doi:10.5194/acp-12-8037-2012, 2012.

Huang, J., Hsu C., Tsay S.-C., Holben B. N., Welton E. J., Smirnov A., Jeong M. J., Hansell R. A., Berkoff T.A., Liu Z., Liu G.-R., Campbell J. R., Liew S. C., and Barnes J. E.: Evaluations of cirrus contamination and screening in ground aerosol observations using collocated lidar systems, J. Geophys. Res., 117, D15204, doi:10.1029/2012JD017757, 2012.

International Cloud Atlas: World Meteorological Organization, Geneva, Switzerland, 11, 1987.

IPCC: Climate Change 2013: The Physical Science Basis. Contribution of Working Group I to the Fifth Assessment Report of the Intergovernmental Panel on Climate Change. Cambridge University Press, Cambridge, UK and New York, NY, USA, 1535 pp. 2013.

Ivanov V. A., Elokhov A. S., and Postylyakov O. V.: On the Possibility of Estimating the Volume of $\mathrm{NO}_{2}$ Emissions in Cities Using Zenith Spectral Observations of Diffuse Solar Radiation near $450 \mathrm{~nm}$, Atmospheric and Oceanic Optics, 25, 434-439, 2012.

Jeong M. J. and Li, Z.: Separating real and apparent effects of cloud, humidity, and dynamics on aerosol optical thickness near cloud edges, J. Geophys. Res., 115, D00K32, doi:10.1029/2009JD013547, 2010.
Kadygrov E. N., Shur G. N., and Viazankin A. S.: Investigation of atmospheric boundary layer temperature, turbulence, and wind parameters on the basis of passive microwave remote sensing, Radio Sci., 38, 8048, doi:10.1029/2002RS002647, 2003.

Kulbachevski, A. O.: Report on the State of the Environment in Moscow in 2013, The Department for nature use and environment protection of Moscow Government, available at: http: //www.mosecom.ru/reports/2013/report2013.pdf (last access: 31 January 2016), 224 pp., 2014 (in Russian).

Madronich S. and Flocke S.: Handbook of Environmental Chemistry, edited by: Boule, P., Springer-Verlag, Heidelberg, Germany, 1-26, 1998.

Martin, R. V., Chance, K., Jacob, D. J., Kurosu, T. P., Spurr, R. J. D., Bucsela, E., Gleason, J. F., Palmer, P. I, Bey, I., Fiore, A .M., Li, Q., Yantosca, R. M., and Koelemeijer, R. B. A.: An improved retrieval of tropospheric nitrogen dioxide from GOME, J. Geophys. Res., 107, 1-21, doi:10.1029/2001JD001027, 2002.

Martin, R. V., Sioris, C. E., Chance, K., Ryerson, Th. B., Wooldridge, P. J., Cohen, R. C., Neuman, J. A., Swanson, A., and Flocke, F. M.: Evaluation of space-based constraints on global nitrogen oxide emissions with regional aircraft measurements over and downwind of eastern North America, J. Geophys. Res., 111, doi:10.1029/2005JD006680, 2006.

Mazin, I. P. and Hrgian, A. H.: Handbook of clouds and cloudy atmosphere, Hydromet Publishing House, Leningrad, Russia, 647 pp., 1989.

Ohvril, H., Teral, H., Neiman, L., Uustare, M., Tee, M., Russak, V., Kallis, A., Okulov, O., Terez, E., Terez, G., Guschin, G., Abakumova, G., Gorbarenko, E., Tsvetkov, A., and Laulainen, N.: Global dimming and brightening versus atmospheric column transparency, Europe, 1906-2007, J. Geophys. Res., 114, D00D12, doi:10.1029/2008JD010644, 2009.

O’Neill, N. T., Eck, T. F., Holben, B. N., Smirnov, A., and Dubovik, O.: Bimodal size distribution influences on the variation of Angstrom derivatives in spectral and optical depth space, J. Geophys. Res.-Atmos., 106, 9787-9806, 2001.

O'Neill, N., Eck, T. F., Smirnov, A., Holben, B. N., and Thulasiraman, S.: Spectral discrimination of coarse and fine mode optical depth, J. Geophys. Res., 108, 4559-4573, doi:10.1029/2002JD002975, 2003.

Putaud, J. P., Cavalli, F., Martins dos Santos, S., and Dell' Acqua, A.: Long-term trends in aerosol optical characteristics in the Po Valley, Italy, Atmos. Chem. Phys., 14, 9129-9136, doi:10.5194/acp14-9129-2014, 2014.

Quaas, J., Stevens, B., Stier, P., and Lohmann, U.: Interpreting the cloud cover - aerosol optical depth relationship found in satellite data using a general circulation model, Atmos. Chem. Phys., 10, 6129-6135, doi:10.5194/acp-10-6129-2010, 2010.

Richter, A., Burrows, J. P., Nüß, H., Granier, C., and Niemeier, U.: Increase in tropospheric nitrogen dioxide over China observed from space, Nature, 437, 129-132, 2005.

Rublev, A. N., Trotsenko, A. N., Trembach, V. V., and Kopylov, A. V.: Online software for simulation of radiation measurements, in IRS 2000: Current Problems in Atmospheric Radiation, edited by: Smith, W. L. and Timofeyev, Y. M., A. Deepak Publishing, Hampton, Virginia, USA, 1105-1108, 2001.

Uliumdzhieva, N., Chubarova, N., and Smirnov, A.: Aerosol characteristics of the atmosphere over Moscow from Cimel sun photometer data, Meteorol. Hydrol., 1, 48-57, 2005. 
Schneider, P., Lahoz, W. A., and van der A, R.: Recent satellitebased trends of tropospheric nitrogen dioxide over large urban agglomerations worldwide, Atmos. Chem. Phys., 15, 12051220, doi:10.5194/acp-15-1205-2015, 2015.

Smirnov, A., Holben, B., Eck, T., Dubovik, O., and Slutsker, I.: Cloud screening and quality control algorithms for the AERONET data base, Remote Sens. Environ., 73, 337-349, 2000.

Su, W., G. L. Schuster, N. G. Loeb, R. R. Rogers, R. A. Ferrare, C. A. Hostetler, J. W. Hair, and Obland M. D.: Aerosol and cloud interaction observed from high spectral resolution lidar data, J. Geophys. Res., 113, D24202, doi:10.1029/2008JD010588, 2008.
Tegen, I., Hollrig, P., Chin, M., Fung, I., Jacob, D., and Penner, J.: Contribution of different aerosol species to the global aerosol extinction optical thickness: Estimates from model results, J. Geophys. Res., 102, 23895-23915, doi:10.1029/97JD01864, 1997.

Yoon, J., Burrows, J. P., Vountas, M., von Hoyningen-Huene, W., Chang, D. Y., Richter, A., and Hilboll, A.: Changes in atmospheric aerosol loading retrieved from space-based measurements during the past decade, Atmos. Chem. Phys., 14, 68816902, doi:10.5194/acp-14-6881-2014, 2014.

WMO: Revised Instruction Manual on Radiation Instruments and Measurements. WCRP Publications Series, No. 7, WMO/TD, No. 149, 1986. 